Article

\title{
Sustained effects of muscle calpain system genotypes on ten- derness phenotypes of South African beef bulls during ageing up to 20 days
}

\author{
Annie Basson 1,2, Phillip E. Strydom ${ }^{3}$, Esté van Marle-Köster ${ }^{2}$, Edward C. Webb ${ }^{2}$ and Lorinda Frylinck ${ }^{1 *}$ \\ ${ }^{1}$ Agricultural Research Council of South Africa; AB: bassona@arc.agric.za; LF: lorinda@arc.agric.za \\ ${ }^{2}$ University of Pretoria; EvMK: este.vanmarle-koster@up.ac.za; EW: edward.webb@up.ac.za \\ ${ }^{3}$ Stellenbosch University; PS: pestrydom@sun.ac.za \\ *Correspondence: lorinda@arc.agric.za
}

\begin{abstract}
Simple Summary: When searching for genetic markers for selection for more tender beef, it is important to maintain minimal environmental variation from pre-laughter, right through to the aging process, to ensure accurate phenotypes. This is because beef quality traits have a large environmental component that can greatly alter the characteristics of the meat, which would not reflect a true genetic effect. We propose that variable aging times are especially important in determining whether markers will associate with tenderization or not. Our analyses included the candidate genes for the protein degrading enzyme system for calpains, because they make the largest contribution to tenderization. We were able to validate these markers in South African beef cattle, where they could be useful for selection. The timing of the collection of tenderness data was critical, as only a few (6/134) genetic markers sustained their association with tenderization over ageing to 20 days. A larger tenderization effect earlier in aging, as shown here for the capn1_187 and capn1_4751 markers would decrease the length of ageing. This will not only increase profits, but also decrease the energy needed during storage and refrigeration of aged beef, decreasing the carbon footprint of beef production.
\end{abstract}

\begin{abstract}
The most important factor that determines beef tenderness is its proteolytic activity and the balance between calpain-1 protease activity and calpastatin inhibition is especially important, while contributions could arise from calpain-2 and possibly calpain-3. These processes are however affected by the meat aging process itself. To determine whether genotypes in the calpain-calpastatin system can enhance tenderness throughout a 20 day aging period, South African purebred beef bulls $(\mathrm{n}=166)$ were genotyped using the Illumina Bovine-HD SNP BeadChip, through gene-based association analysis targeting the cast, capn3, capn 2 and capn1 genes. The Warner-Bratzler shear force (WBSF) and myofibril fragment length (MFL) of Longissimus thoracis et lumborum (LTL) steaks were evaluated between $\mathrm{d} 3-\mathrm{d} 20$ of aging, with protease enzyme activity in the first $20 \mathrm{~h}$ post-mortem. Although several of the 134 SNP associated with tenderness, only seven SNP in the cast, capn 2 and capn1 genes sustained genetic associations, additive to aging-associated increases in tenderness for at least three of the four aging periods. While most genomic associations were relatively stable over time, some genotypes within SNP responded differently to aging, resulting in altered genomic effects over time. The level of aging at which genomic associations are performed is an important factor that determines whether SNP affect tenderness phenotypes.
\end{abstract}

Keywords: SNP; calpain-calpastatin system genes; genomic association; tenderization; ageing

\section{Introduction}

Increased tenderness with beef aging involves weakening of the myofibrillar structure of muscle fibers through the degradation of myofibrillar (and other) proteins [1-3]. 
Proteolysis that occurs due to muscle calpain system activity during aging, results in tenderization [4] and is mainly attributed to calpain-1 [2], with prominent modulating effects of calpastatins [5,6]. The contribution of calpain-2 protease becomes progressively more important as aging progresses [7], while calpain-3 activity could also potentially contribute to ultimate tenderness of beef [8], although this remains controversial. By extending the aging period, tougher steaks that age at a slower rate can achieve greater levels of tenderness [9] and is important in (for example) cattle with a larger Bos indicus genetic background [10], allowing improved quality before going to market. However, this results in logistical challenges of chilled storage and tracking large amounts of beef over extended time periods, whereas the ultimate goal is to accelerate these processes as much as possible [11] and shorten the aging period [12].

The aim of selection to improve tenderness of beef [13], goes hand in hand with the goal to accelerate the aging process, in order to reach ultimate tenderness as rapidly as possible [11]. The efficacy of SNP for selection for tenderness is different between populations [14] and there are genetic differences among beef breeds with regard to the calpain system and expression of tenderness. In South Africa, studies based on high throughput genotyping have been limited and generally focused on genetic characterization and genomic relationships $[15,16]$. Studies on genetic diversity and the application of genomic selection used moderate density SNP arrays like the 50KSNP, [17-20], 80K [21-23] and 150K [16], but these could lack sufficient SNP density for characterization of indigenous beef breeds [23]. Although disease resistance SNP [24] and potential beef quality SNP have been identified [25], association studies using detailed tenderness phenotypes in the calpain-calpastatin system have only been performed with a very limited SNP pool [26].

Genome-wide association studies (GWAS) are useful for determining novel associations with phenotypes, while SNPs within targeted genes give a higher power of association of analysis for quantitative traits [27,28]. The use of candidate genes or gene-assisted selection is effective (given accurate phenotypic data), because even small gains in quantitative traits are economically valuable [29].

The duration of the aging period may affect the estimates of heritability, with variation between breeds and aging time, including interactions between these two variables [30]. This is likely related to the fact that there are differences between the rate of tenderization between different breeds and individual muscles [31], even when breeds were subjected to the same production conditions and/or carcasses to the same post-mortem processing procedures.

Accurate phenotypes are prerequisite for linking genotypic data with traits related to beef quality [32], especially because many of the beef quality phenotypes have a moderate to low heritability $[33,34]$. Tenderness phenotypes under varying environmental conditions (perimortem and post-slaughter practices) are still poorly defined and large data sets with detailed phenotypes and appropriate SNP in the causative genes are lacking. Studies in controlled environmental and slaughter conditions sometimes only include a small number of animals [35,36] and/or a small number of genotypes [35,37] due to the financial costs involved in raising and slaughtering animals. Other genomic association studies of beef quality have pooled data collected from different herds subjected to varying production systems [38-40], with or without electrical stimulation at varying aging periods [38]. Large studies are often constrained by the cost to genotyping [41], so that the number of SNP analyzed was sometimes limited to lower density SNP chips, like $7 \mathrm{~K}-150 \mathrm{~K}$ [42,43], inferred through imputation [40,44] or only a few individual SNP from causal genes were used [35,37-39,45,46]. Data from Bos indicus using a limited capn1 and cast SNP pool suggested that aging time $(\leq 21 \mathrm{~d})$ may alter genomic associations [45], while it has been suggested that aging decays genetic associations with tenderness phenotypes over time $[47,48]$. Few studies have explored the effect of different post-slaughter practices like aging period on the association between genotypes and tenderness phenotypes $[39,45,49,50]$ and many studies used a limited number of single 
nucleotide polymorphisms (SNP), while no data is available from South African beef cattle.

Augmentation of tenderness through post-mortem practices like electrical stimulation, tenderstretch or extended aging could eliminate differences in tenderness over time [9], altering genomic associations depending on the relationship between sample collection and these factors [45] and making selection less effective. To determine whether extended aging affected genomic association between candidate SNP and tenderness, we performed a regional, gene-based association study using the Illumina Bovine-HD (777K) BeadChip focusing on the genes of the calpain-calpastatin system over 20 days of aging. This is the first study to explore the association between Bovine-HD SNP of the cast (chromosome 7), capn-3 (chromosome 10), capn-2 (chromosome 16) and capn-1 (chromosome 29) genes with tenderness (WBSF and MFL) up to 20 days of aging in South African beef cattle. The objective of this study was to determine whether favorable genotypes in causative genes for tenderness could improve the phenotype over extended aging up to 20 days and whether these associations were similar over aging periods and between breeds.

\section{Materials and Methods}

\subsection{Animals}

Purebred bulls of approximately nine months old were feedlot-finished for approximately 120 days at the Animal Production Unit of the Agricultural Research Council (ARC-AP) unit in Irene, Pretoria $-25^{\circ} 54^{\prime} 28^{\circ} 12^{\prime}$, altitude $\geq 1475 \mathrm{~m}$. Five breeds were included in the study (Table 1) as representative of breed types. Angus were representative of British Bos taurus, Charolais European Bos taurus, Brahman Bos indicus, Bonsmara as an indigenous Sanga-type composite breed and Nguni as the indigenous Sanga-type, Bos taurus africanus. Bulls were slaughtered to yield A2/A3 class carcasses [51,52], meaning zero permanent incisors, with lean to medium fatness and were approximately 12 months old at slaughter. Standard management and slaughter practices were used to minimize the variation in tenderness induced by environmental factors, and the same feedlot, abattoir and similar carcass handling and aging procedures were used for all bulls. 
Table 1. Descriptive statistics - means of the pooled data of all breeds and least squares means within breeds of production and tenderness data of South African feedlot-finished beef bulls

\begin{tabular}{|c|c|c|c|c|c|c|c|c|}
\hline & $\begin{array}{c}\text { All Breeds } \\
(\mathrm{n}=166)\end{array}$ & & $\begin{array}{l}\text { Angus } \\
(\mathrm{n}=24)\end{array}$ & $\begin{array}{c}\text { Bonsmara } \\
(\mathrm{n}=35)\end{array}$ & $\begin{array}{c}\text { Brahman } \\
(n=35)\end{array}$ & $\begin{array}{c}\text { Charolais } \\
(\mathrm{n}=34)\end{array}$ & $\begin{array}{l}\text { Nguni } \\
(\mathrm{n}=35)\end{array}$ & ${ }^{\sharp P}$-value \\
\hline BW (kg) & $388 \pm 4.26$ & & $422^{a} \pm 9.65$ & $399^{b} \pm 4.26$ & $393^{b} \pm 7.44$ & $423^{a} \pm 5.39$ & $308^{c} \pm 3.39$ & 0.0001 \\
\hline $\begin{array}{l}\text { 35dADG } \\
(\mathrm{kg} / \mathrm{d})\end{array}$ & $1.54 \pm 0.04$ & & $1.81^{b} \pm 0.08$ & $1.62^{\mathrm{ab}} \pm 0.05$ & $1.37 \mathrm{a} \pm 0.06$ & $1.88^{c} \pm 0.09$ & $1.21^{\mathrm{c}} \pm 0.07$ & 0.0001 \\
\hline HCW (kg) & $219 \pm 2.46$ & & $234^{\mathrm{ab}} \pm 5.36$ & $223^{b} \pm 2.87$ & $226^{b} \pm 4.67$ & $240^{a} \pm 3.44$ & $174^{c} \pm 2.07$ & 0.0001 \\
\hline CCW (kg) & $215 \pm 2.42$ & & $229^{a b} \pm 5.29$ & $218^{\mathrm{b}} \pm 2.82$ & $221^{\mathrm{b}} \pm 4.67$ & $234^{a} \pm 3.34$ & $170 c \pm 2.09$ & 0.0001 \\
\hline Dressing\% & $56.53 \pm 0.15$ & & $55.62^{b} \pm 0.33$ & $55.96^{b} \pm 0.33$ & $57.44^{\mathrm{a}} \pm 0.24$ & $56.64^{\mathrm{ab}} \pm 0.36$ & $56.44^{\mathrm{ab}} \pm 0.34$ & 0.0004 \\
\hline Mass Loss (\%) & $2.18 \pm 0.03$ & & $2.16 \pm 0.07$ & $2.30 \pm 0.06$ & $2.22 \pm 0.08$ & $2.25 \pm 0.07$ & $2.14 \pm 0.09$ & 0.0564 \\
\hline EMA $\left(\mathrm{mm}^{2}\right)$ & $6084 \pm 64$ & & $5853^{\mathrm{cd}} \pm 127$ & $6364^{\mathrm{ab}} \pm 134$ & $5922^{b c} \pm 121$ & $6647^{a} \pm 127$ & $5444^{\mathrm{d}} \pm 120$ & 0.0001 \\
\hline WBSF (d3) & $6.15 \pm 0.09$ & & $5.89 \mathrm{~b} \pm 0.20$ & $5.74^{b} \pm 0.20$ & $6.63 a \pm 0.19$ & $6.09 \mathrm{ab} \pm 0.21$ & $6.17 \mathrm{ab} \pm 0.24$ & 0.0122 \\
\hline WBSF (d9) & $4.83 \pm 0.08$ & $-21.4 \%^{1}$ & $4.41^{\mathrm{b}} \pm 0.16$ & $4.53^{b} \pm 0.15$ & $5.38^{a} \pm 0.21$ & $4.88^{\mathrm{ab}} \pm 0.19$ & $4.75^{\mathrm{b}} \pm 0.21$ & 0.0006 \\
\hline WBSF (d14) & $4.17 \pm 0.07$ & $-32.3 \%^{1}$ & $3.75^{b} \pm 0.11$ & $4.20^{\mathrm{ab}} \pm 0.15$ & $4.55^{a} \pm 0.15$ & $4.08^{\mathrm{ab}} \pm 0.16$ & $3.99^{b} \pm 0.19$ & 0.0028 \\
\hline WBSF (d20) & $3.87 \pm 0.07$ & $-37.1 \%^{1}$ & $3.64^{\mathrm{ab}} \pm 0.13$ & $4.08^{a} \pm 0.15$ & $4.09 a \pm 0.15$ & $3.82^{\mathrm{ab}} \pm 0.14$ & $3.52^{b} \pm 0.15$ & 0.0022 \\
\hline$\% \Delta \mathrm{WBSF}^{2}$ & & & $-38.3 \%$ & $-28.9 \%$ & $-38.3 \%$ & $-37.3 \%$ & $-42.9 \%$ & \\
\hline MFL (d3) & $35.51 \pm 0.48$ & & $36.35^{\mathrm{ab}} \pm 1.17$ & $31.74^{c} \pm 0.87$ & $39.65^{\mathrm{a}} \pm 1.23$ & $35.53^{b} \pm 0.95$ & $32.93^{\mathrm{bc}} \pm 0.79$ & 0.0001 \\
\hline MFL (d9) & $26.21 \pm 0.31$ & $-26.2 \%^{1}$ & $25.55^{\mathrm{bc}} \pm 0.66$ & $23.57^{c} \pm 0.47$ & $29.08^{a} \pm 0.84$ & $26.65^{b} \pm 0.73$ & $25.35^{c} \pm 0.49$ & 0.0001 \\
\hline MFL (d14) & $23.92 \pm 0.28$ & $-32.6 \%{ }^{1}$ & $22.87 \mathrm{bc} \pm 0.57$ & $22.07^{`} \pm 0.44$ & $25.91^{\mathrm{a}} \pm 0.71$ & $24.67^{\mathrm{ab}} \pm 0.79$ & $23.72^{\mathrm{bc}} \pm 0.48$ & 0.0001 \\
\hline MFL (d20) & $21.66 \pm 0.23$ & $-39.0 \% \%^{1}$ & $20.74^{\mathrm{bc}} \pm 0.49$ & $19.88^{c} \pm 0.40$ & $22.93^{a} \pm 0.54$ & $22.60^{a} \pm 0.57$ & $21.90^{\mathrm{ab}} \pm 0.45$ & 0.0001 \\
\hline$\% \Delta \mathrm{MFL}^{2}$ & & & $-42.9 \%$ & $-37.4 \%$ & $-42.2 \%$ & $-36.4 \%$ & $-33.5 \%$ & \\
\hline
\end{tabular}

Least squares means (LSM) \pm standard errors (SE) that were significantly different between breeds $(P \leq 0.05)$ were indicated with different ascending letter superscripts $(\mathrm{a}, \mathrm{b}, \mathrm{c})$ in each row.

${ }^{\text {"P}} P$-values derived from a GLM; ${ }^{1}$ The difference in tenderness at the aging period, compared to $\mathrm{d} 3$ post-mortem; ${ }^{2}$ The difference in tenderness on $\mathrm{d} 20$ compared to $\mathrm{d} 3$ post-mortem within each breed.

35dADG - average daily gain recorded over the last 35 days before slaughter; $\mathrm{BW}$ - live body weight at slaughter; CCW - cold carcass weight; EMA - eye muscle area; HCW - hot carcass weight; MFL - myofibril fragment length $(\mu \mathrm{m})$; WBSF - Warner-Bratzler shear force $(\mathrm{kg})$. 


\subsection{Slaughter and sampling}

Bulls were transported to the ARC-AP abattoir $(3.9 \mathrm{~km}$ from the feedlot) and held overnight with access to water. Following captive bolt stunning and exsanguination, bulls were slaughtered, carcasses were halved and the right half of each carcass was electrically stimulated for $15 \mathrm{~s}$ (500 V peak, $5 \mathrm{~ms}$ pulses at 15 pulses/s) and chilled directly (ES). The left half of each carcass served as a control and chilling was delayed for $6 \mathrm{~h}$ post-mortem (NS) to allow for accelerated conditioning at $10^{\circ} \mathrm{C}$ before chilling.

Association analyzes were originally performed on the left half and the right half of the carcasses separately, as well as the pooled data. Of all the association analyzes performed (NS, ES, NS+ES) for each SNP and phenotype, only 0.3\% exhibited genotypextreatment interactions (results not shown) and did not include any of the candidate SNP identified here. In order to simplify data representation tables, only data from the NS+ES analysis is represented here and any notable differences between association analyzes described in the text.

Meat or tail hair samples were collected at slaughter. Meat samples were stored at $-20{ }^{\circ} \mathrm{C}$ until extraction of DNA from a core sample, while tail hair were stored at room temperature until extraction of DNA from hair bulbs. At approximately $20 \mathrm{~h}$ post-mortem, the Longissimus lumborum et thoracis (LTL; loin) muscle was excised (boned-out). Several $30 \mathrm{~mm}$ steaks were collected from predetermined regions of the LTL for each of the laboratory analyzes for each aging period, vacuum-sealed (70 microns) and aged for three, nine, 14 and 20 days post-mortem at $2 \pm 1{ }^{\circ} \mathrm{C}(\mathrm{d} \mathrm{3}, \mathrm{d} 9, \mathrm{~d} 14, \mathrm{~d} 20)$. The myofibril fragment length (MFL) was determined following aging, while steaks for the determination of Warner-Bratzler shear force (WBSF) were frozen at $-20^{\circ} \mathrm{C}$ until analyzed. Small sub-samples were collected from the lumbar portions of the LTL at $1 \mathrm{~h}$ and $20 \mathrm{~h}$ post-mortem, snap-frozen to $-196^{\circ} \mathrm{C}$ in liquid nitrogen and immediately stored at $-80^{\circ} \mathrm{C}$ until analyzes of muscle calpains and calpastatin activities.

\subsection{Tenderness}

For WBSF measurements [53], steaks were thawed overnight, oven-grilled at $200^{\circ} \mathrm{C}$ to a core temperature of $70^{\circ} \mathrm{C}$ and cooled to $18^{\circ} \mathrm{C}$ for core sample collection. A handheld cork borer (12.7 mm diameter) was used to collect six round, uniform cores from each steak, parallel to muscle fiber direction. Core samples were sheared through the center, perpendicular to the long axis of the muscle fibers with a Universal Instron apparatus (Instron Ltd, Buckinghamshire, England) fitted with a Warner-Bratzler V-notched shear blade (60 angle) [54]. The crosshead speed of the Instron apparatus was set to $200 \mathrm{~mm} / \mathrm{min}$ and the peak force $(\mathrm{kg})$ for each core was determined.

The MFL was determined following extraction according to Culler et al. (1978) as modified by Heinze \& Bruggemann (1994) [1,55]. The mean of 100 fragments per steak (or aging period) was determined using Video Image Analysis (VIA) with an Olympus System microscope, model BX40 (Tokyo, Japan) at a 400× magnification equipped with CC12 video camera.

\subsection{Muscle calpain protease system}

Calpain-1, calpain-2 and calpastatin were extracted from muscle tissue samples and separated by 2-step gradient ion exchange chromatography [56]. Using azo-casein substrate [57], a unit of calpain protease activity was defined as a 1.0/h increase in absorbance at $366 \mathrm{~nm}\left(A_{336}\right)$ at $25^{\circ} \mathrm{C}$, while protease inhibition by calpastatin was defined as the amount required to inhibit one unit of calpain-2 activity. Enzyme activities and inhibition were expressed as units per grams of meat, while relative units of inhibition by calpastatin per units of calpain-1, or per the combined protease activities of calpain-1 and calpain-2, were also calculated.

2.5 DNA extraction and genotyping

DNA was collected from muscle or hair samples and extracted using the NucleoSpin ${ }^{\circledR}$ Tissue kit (Macherey-Nagel GmbH \& Co. KG, Germany) with silica membrane columns, including modifications to the basic protocol to enhance DNA yield, as per the 
user manual. Samples were allowed to stabilize overnight at $4{ }^{\circ} \mathrm{C}$ and DNA quality and concentration were determined at the Agricultural Research Council, Animal Genetics (South Africa) using UV spectrometry (NanoDrop2000/2000c, Thermo Fisher Scientific, USA), fluorometry (Qubit ${ }^{\circledR}$ 3.0, Thermo Fisher Scientific, USA) and ethidium bromide agarose gel electrophoresis.

All the animals were individually genotyped using the Bovine-HD SNP BeadChip (Illumina, USA), using the HiScanSQ platform and Genome Studio software (Illumina, USA) at the Agricultural Research Council, Biotechnology Platform (South Africa). The National Centre for Biotechnology Information (NCBI) Genome Data Viewer [58], using bovine genome assembly UMD3.1.1, was used to determine the extent of the four muscle calpain system gene transcripts (gene $\pm 8 \%$ length). The number of variants that fell within the range for each gene (before quality control) were 12 for the capn 1 gene (chromosome 29, 44,223 bp), 27 for capn2 (chromosome 16, 70,008 bp), 18 for capn3 (chromosome $10,68,507 \mathrm{bp}$ ) and 77 for cast $(163,722 \mathrm{bp})$. For each SNP, the name was abbreviated as the gene plus the last three digits of the Illumina code (gene_123), except for the SNP capn1-4751, which was abbreviated from the Illumina CANP1_2 to capn1_4751. The allele that favored tenderness was determined by comparing phenotypic means of the three genotypes, first for the genotype with the lowest WBSF and then MFL (if necessary), where these alleles were indicated with an asterisk and designated the tender allele $\left(\mathrm{A}^{*} / \mathrm{C}^{*} / \mathrm{G}^{*} / \mathrm{T}^{*}\right)$ that codes for the tender form of the protein. This simplified designation of the alleles was possible, because no dominance effects were found in the candidate SNP effects.

Quality control was performed on the SNP using PLINK version 1.9 software [59] to exclude SNP with a genotyping (call) rate $<0.95$, deviation from Hardy-Weinberg distribution $\left(P_{\mathrm{HWdev}} \leq 1 \times 10^{-4}\right)$ and minor allelic frequency $<5 \%$. Five SNP were disqualified during quality control, two from the capn3 gene, two from the capn 2 gene and one from the cast gene.

\subsection{Statistical analyses}

A mixed linear model association (mlma) analysis [60] was conducted to determine the association of genotypes with the tenderness phenotypes, using GCTA 1.92 .2 software [61] (University of Queensland, Australia). The simplified mixed model used the genotype of the different SNP $(b x)$ as a fixed effect in a linear model, with a variance-standardized genomic relationship matrix $(g)$ as a random accumulated effect of all SNP and the residual ( $e$ ) or random effect of error. To determine whether these responses were similar between breeds, associations were performed within breeds, with all breeds as covariates or with each individual breed added to the simplified model as covariate fixed effects ( $\left.\operatorname{covar}_{B r}\right)$ :

$$
y=a+b x+\left[\operatorname{covar}_{B r}\right]+g+e
$$

To determine the least squares means (LSM) of genotypes or genotypes within breeds, Statistical Analysis System (SAS Institute, Cary, NC) software was used [62] to determine the least significant difference $(\alpha=0.05)$. A generalized linear model procedure was conducted including the effects of genotype $(G e)$ of the SNP, electrical stimulation treatment $(T m t)$, breed $(B r)$, first order interactions with genotype as well as residual $(e)$ :

$$
y=\mu+G e+T m t+B r+G e T m t+G e B r+e
$$

Because individual SNP in a gene are not independent (genotypes of different closely associated SNP are linked in inheritance or pleiotropy), a linkage disequilibrium (LD) analysis was performed using Haploview 4.2 software (Broad Institute, USA) [63] default analysis [64]. The LD indicates a link between genotypes (alleles at different loci) 
that is greater than that attributed to chance, i.e. LD $[65,66]$. This implies that, through this association, selection for one SNP with a high level of LD with another SNP, would indirectly result in selection for the other SNP, as they are not genetically independent.

SNP with Lewontin's D-prime (D') that is greater than the threshold of 0.95 are likely to also be affected when a candidate SNP is included in a selection program. All SNP that were identified as dependent on a candidate SNP that had additive effects through extended aging, were also subjected to the gene-based association analyzes to ensure the direction of change in tenderness phenotypes were also positive and that no (readily apparent) inadvertent negative effects were linked to the SNP that sustained tenderness over extended aging.

\section{Results}

\subsection{Tenderness}

On d 3 post-mortem, Brahman cattle had the toughest beef based on the highest WBSF values, while Bonsmara was the most tender, but was not different from Angus (Table 1; Figure 1a). The WBSF of Charolais and Nguni were intermediate in toughness. All breeds experienced a significant increase in tenderness between $\mathrm{d} 3$ to $\mathrm{d} 9$, of between $19 \%$ in Brahman and 25\% in Angus. This was followed by another $15-16 \%$ decrease in shear force values to d 14, except Bonsmara where the decrease in WBSF (i.e. improvement in tenderness) was only $7 \%$. Between $\mathrm{d} 14$ to $\mathrm{d} 20$ there was little or no change in WBSF in Angus and Bonsmara (3\% lower), a moderate tenderization in Charolais (6\% lower) and continued tenderization in Brahman (10\% lower) and Nguni (12\% lower WBSF). This meant that Nguni had the most tender beef on d 20 and WBSF was $13.9 \%$ lower than Bonsmara, while Brahman had the highest WBSF scores at this stage of aging (and Angus and Charolais had intermediate values).

MFL on d 3 was the shortest in Bonsmara and longest in Brahman (Figure 1b). MFL in Nguni, Angus and Charolais were similar in myofibril length, where Nguni did not differ from Bonsmara (intermediate-short) and Angus did not differ from Brahman (intermediate-long). All breeds experienced a large decrease in MFL between $\mathrm{d} 3$ to d 9 post-mortem, which related to $23 \%$ in Nguni and 30\% in Angus. The reduction in MFL to d 14 was $10 \%$ in Angus and 11\% in Brahman, where the decrease in length of other breeds was $6-7 \%$. On d 20, MFL was still decreasing from d 14 values by between $8 \%$ in Nguni and 10\% in Brahman. Although Brahman had the greatest absolute decrease in myofibril lengths (16.72 $\mu \mathrm{m}$ shorter), the long initial MFL was not overcome by aging and it remained the highest of all breeds (with Charolais) on d 20 of aging. In Bonsmara the MFL remained the shortest throughout the entire aging period (-12.7\% of Brahman and Charolais), while Nguni had intermediate-high MFL (3.8\% shorter) and Angus intermediate-low MFL (8.9\% shorter MFL) on d 20.

3.2 SNP

Ten candidate SNP were identified in this study that could affect tenderness over extended aging periods, for at least three out of the four aging periods measured (from a pool of 134 SNP in the four genes). Of these, one SNP was eliminated in quality control measures, due to a very low minor allelic frequency, which can result in false positives. Another two SNP, one in the cast gene and one in the capn2 gene were statistically significant, but biologically negligible as the differences in LSM between genotypes were very small. 
(a)

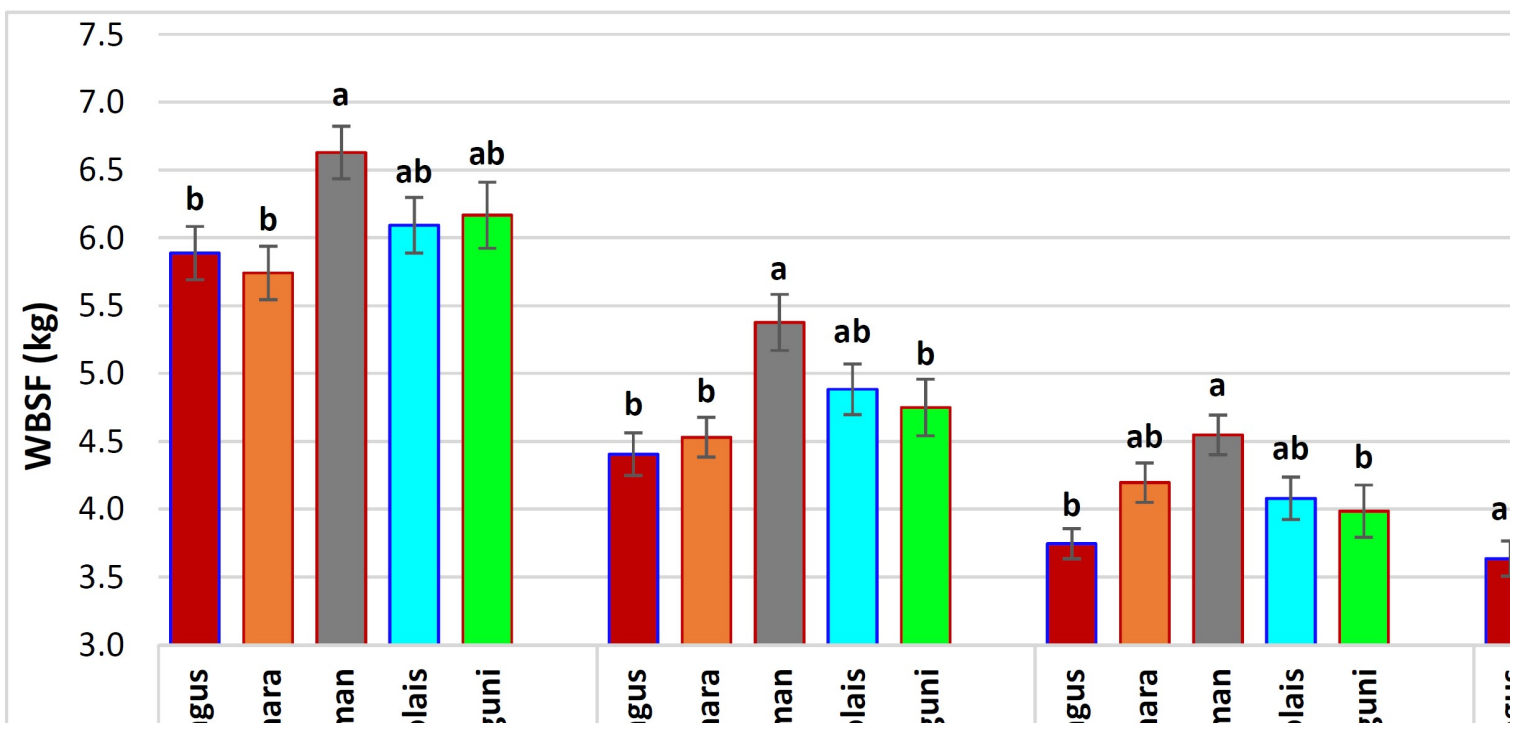

(b)

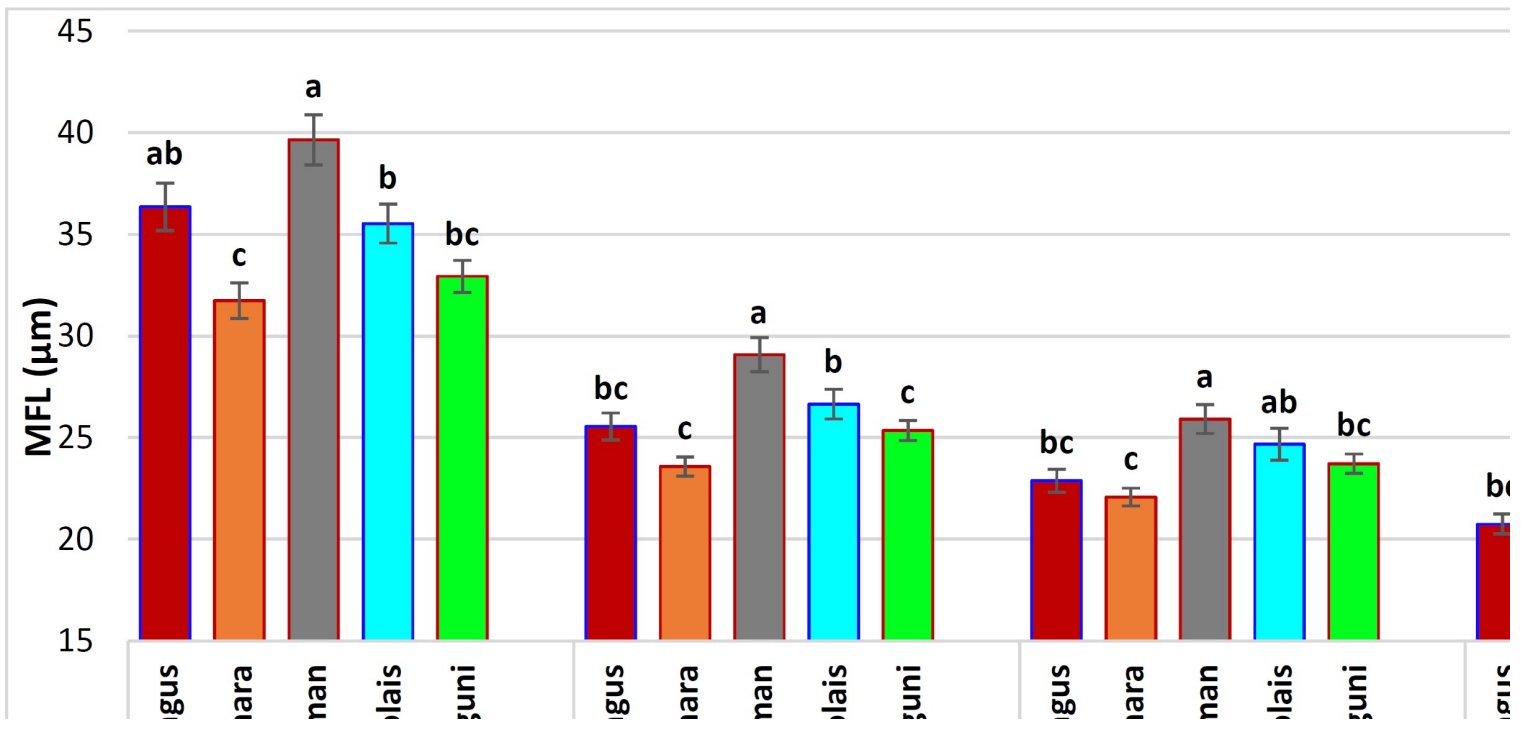

Figure 1. Changes in tenderness in five South African beef breeds over an ageing period of 20 days. Least squares means (LSM) that were statistically significantly different within ageing periods $(\mathrm{P} \leq 0.05)$ are indicated with different ascending letter superscripts $(a, b, c)$. Error bars represent the standard errors of these LSM: (a) WBSF - Warner-Bratzler shear force; (b) MFL - myofibril fragment length.

\subsection{1 cast_736}

The cast_736 SNP (rs137217365) is located $28.81 \mathrm{~kb}$ from the start of the cast gene. The SNP is independent, i.e. it did not exhibit LD (D'>0.95) with any of the other SNP of the cast gene. It seems therefore that there will not be unintended effects of non-random inheritance from nearby loci. The genotype that favored tenderness, or tender genotype $\mathrm{GG}^{*}$, was relatively rare, and occurred in only 19 of the 166 bulls (11\%). However, data from bulls with the heterozygous genotype showed intermediate tenderizing effects, confirming the effects of the $\mathrm{G}^{*}$ allele.

The cast_736 genotype (Table 2) was associated with biologically small changes in WBSF in the early aging periods on $d 3$ and d 9 post-mortem $(\leq 5.1 \%)$, but resulted a larger decrease in shear force on $\mathrm{d} 14$, while the tenderizing effect on d 20 was not statistically significant $(P \leq 0.1343)$. The $0.43 \mathrm{~kg}$ decrease in shear force on $\mathrm{d} 14$ in $\mathrm{GG}^{*}$ bulls was 
additive to a tenderizing effect of aging that had resulted in an almost $2 \mathrm{~kg}$ decrease in shear force values in all three genotypes. This means that the tender genotype was still able to induce a $10.3 \%$ increase in tenderization in the face of existing tenderization of aging at 14 days of $36.0 \%$ compared to $d 3$. The addition of breeds to the simplified model as covariates, each breed as a covariate or within-breed analyzes suggest that the effects of this genotype on WBSF were not breed dependent.

The cast_736 SNP was associated with MFL over the aging period between $\mathrm{d} 9$ to d 20, with little advantage to adding breed to the model. However, the phenotypic response to genotypes was greatly altered by the time of the aging period. The MFL on d 9 tended to reach significance, but the response in the $\mathrm{GG}^{*}$ genotype was an increase in myofibril length of $1.70 \mu \mathrm{m}$, which would not favor tenderization. At this aging period, the only significant breed-dependent effect was identified in Charolais that was the only breed to exhibit a decrease in MFL of $6.9 \%$ or $1.94 \mu \mathrm{m}$ (within-breed $P \leq 0.0404$ ). On d 14 post-mortem, the genotypes failed to result in biologically important changes in MFL compared to TT $(+0.9 \%)$, but was $4.2 \%$ shorter than GT. The association of MFL with genotypes on d 20 resulted in a relatively small decrease in myofibril length $(1.01 \mu \mathrm{m}$ shorter) that occurred in addition to the large tenderizing effects induced by aging. During the period where the cast_736 SNP affected MFL $(\mathrm{d} 9-\mathrm{d} 20)$, aging resulted in a $4.53 \mu \mathrm{m}$ decrease in myofibril lengths in TT bulls and $4.10 \mu \mathrm{m}$ in GT, while at the same time, $\mathrm{GG}^{*}$ bulls experienced a $7.24 \mu \mathrm{m}$ decrease in MFL.

The lack of consistent response in MFL and the small changes in WBSF can be explained by the differences between genotypes in the muscle protease system. The genotype did not affect calpain protease activities, while small and inconsistent associations were noted for calpastatin inhibition, at $1 \mathrm{~h}$ post-mortem only (Table 2). The LSM of absolute calpastatin inhibition at one hour was not different between genotypes, but tended to associate with inhibition in the mixed linear model. The relative inhibition of calpain-1 by calpastatin at $1 \mathrm{~h}$ was decreased by $5.9 \%$ in $\mathrm{GG}^{*}$ bulls, while the decrease per units of calpain-1 and calpain-2 activity was biologically negligible.

3.2.2 cast_763

The cast_763 SNP (rs135465452) is located $98.91 \mathrm{~kb}$ from the start of the gene and was in strong LD ( $\left.\mathrm{D}^{\prime}>0.95\right)$ with several SNP associated with tenderness phenotypes (results not shown). When determining whether cast_763 would be a suitable candidate for selection for tenderness that is sustained in the face of aging, it is important to note whether the closely-linked SNP also induced positive tenderizing effects, as selection for the candidate SNP would indirectly result in selection for SNP in high LD. These SNP included cast_741 (-50.0 kb from cast_763), cast_770 (+17.2 kb from cast_763); cast_771 (17.9 kb); cast_772 $(18.9 \mathrm{~kb})$ and cast_779 $(36.9 \mathrm{~kb})$. Although none of these SNP were identified as candidate SNP for improvement of tenderness over extended aging periods, they were found to have associations with some tenderness phenotypes (unpublished results). The corresponding alleles for these SNP were also favorable for tenderness and the general effects of these SNP were mild reductions in WBSF between $\mathrm{d} 3$ to $\mathrm{d} 14$ (of between $6.7-9.0 \%)$, with generally small improvements in MFL on d $14(5.0-6.5 \%)$.

The cast_763 SNP did not associate with WBSF at any of the aging periods, but was associated with MFL throughout the entire aging period between $\mathrm{d} 3$ and $\mathrm{d} 20$ of aging in the simplified model (Table 3). Although the responses in MFL at these aging periods were biologically small $(4.4-5.5 \%)$, the differences between LSM for the tender, CC* genotype reached significance compared to $\mathrm{CT}$. The tenderizing effect of the genotype was additive to an already-tenderizing effect of aging on MFL between d $3-\mathrm{d} 20$ of $39 \%$ for both genotypes. There was no advantage in the addition of breed(s) to the simplified model. 
Table 2. The effects of genotype of the cast_736 SNP on the tenderness phenotypes, Warner-Bratzler shear force (WBSF) and myofibril fragment length (MFL) of representative purebred South African beef bulls during three to 20 days of aging and on the muscle protease enzyme system during the first 20 hours post-mortem

\begin{tabular}{|c|c|c|c|c|c|}
\hline cast_736 & ${ }^{*} \mathrm{GG}(\mathrm{n}=19)$ & GT $(n=54)$ & $\mathrm{TT}(\mathrm{n}=93)$ & $\begin{array}{l}P \text {-value } \\
(\text { simplified) }\end{array}$ & $\begin{array}{l}\text { Genotype } \\
\text { effect }\end{array}$ \\
\hline WBSF (d3) & $5.90^{\mathrm{b}} \pm 0.38$ & $6.05^{\mathrm{ab}} \pm 0.17$ & $6.22^{a} \pm 0.12$ & 0.0130 & $-5.1 \%$ \\
\hline WBSF (d9) & $4.70^{\mathrm{b}} \pm 0.33$ & $4.77^{a b} \pm 0.14$ & $4.92^{a} \pm 0.11$ & 0.0111 & $-4.6 \%$ \\
\hline WBSF (d14) & $3.78^{y} \pm 0.28$ & $4.17^{z} \pm 0.12$ & $4.21^{z} \pm 0.09$ & 0.0950 & $-10.3 \%$ \\
\hline WBSF (d20) & $3.63 \pm 0.27$ & $3.89 \pm 0.12$ & $3.90 \pm 0.09$ & 0.1343 & - \\
\hline MFL (d3) & $39.29 \pm 1.89$ & $34.51 \pm 0.81$ & $35.64 \pm 0.61$ & 0.4293 & - \\
\hline MFL (d9) & $28.20^{z} \pm 1.23$ & $25.36 y \pm 0.53$ & $26.50 y \pm 0.40$ & 0.0895 & $+6.4 \%$ \\
\hline MFL (d14) & $24.42^{\mathrm{a}} \pm 1.16$ & $23.17^{b} \pm 0.50$ & $24.20^{\mathrm{ab}} \pm 0.38$ & 0.0074 & ${ }^{\#}-4.2 \%$ \\
\hline MFL (d20) & $20.96^{\mathrm{b}} \pm 0.94$ & $21.26^{\mathrm{b}} \pm 0.41$ & $21.97 \mathrm{a} \pm 0.31$ & 0.0448 & $-4.6 \%$ \\
\hline calpastatin (1h) & $2.15^{z} \pm 0.10$ & $2.03 y \pm 0.04$ & $2.02^{y} \pm 0.03$ & 0.0811 & $+6.4 \%$ \\
\hline calpastatin (20h) & $1.87 \pm 0.12$ & $1.66 \pm 0.05$ & $1.72 \pm 0.04$ & 0.1819 & - \\
\hline calpain-1 (1h) & $1.53 \pm 0.08$ & $1.46 \pm 0.04$ & $1.40 \pm 0.03$ & 0.8459 & - \\
\hline calpain-1 (20h) & $1.17 \pm 0.09$ & $1.06 \pm 0.04$ & $1.10 \pm 0.03$ & 0.3287 & - \\
\hline calpain-2 (1h) & $1.02 \pm 0.04$ & $1.00 \pm 0.02$ & $0.98 \pm 0.01$ & 0.3944 & - \\
\hline calpain-2 (20h) & $1.03 \pm 0.04$ & $1.02 \pm 0.02$ & $1.01 \pm 0.01$ & 0.4279 & - \\
\hline calpastatin/calpain-1 (1h) & $1.40^{\mathrm{b}} \pm 0.07$ & $1.44^{\mathrm{ab}} \pm 0.03$ & $1.49^{\mathrm{a}} \pm 0.02$ & 0.0398 & $-5.9 \%$ \\
\hline calpastatin/calpain-1 (20h) & $1.66 \pm 0.13$ & $1.80 \pm 0.06$ & $1.68 \pm 0.04$ & 0.9142 & - \\
\hline calpastatin/calpains(1h) & $0.84 \pm 0.03$ & $0.84 \pm 0.01$ & $0.86 \pm 0.01$ & 0.0105 & $\mathrm{n} / \mathrm{a}$ \\
\hline calpastatin/calpains (20h) & $0.83 \pm 0.04$ & $0.82 \pm 0.02$ & $0.81 \pm 0.01$ & 0.1441 & - \\
\hline
\end{tabular}

${ }^{*} \mathrm{GG}$ - the genotype that favored tenderness; Least squares means (LSM) \pm standard errors (SE) that were significantly different within rows or aging periods $(\mathrm{P} \leq 0.05)$ were indicated with different ascending letter superscripts and those that tended to be significantly different $(\mathrm{P} \leq 0.10)$, with different descending letter superscripts $(\mathrm{z}, \mathrm{y}, \mathrm{x})$. $\mathrm{n} / \mathrm{a}$ - LSM differences were biologically negligible.

\# means difference of $\mathrm{GG}^{*}$ compared to GT; MFL - myofibril fragment length; WBSF - Warner-Bratzler shear force. 
Table 3. The effects of genotype of the cast_763 SNP on the tenderness phenotypes, Warner-Bratzler shear force (WBSF) and myofibril fragment length (MFL) of representative purebred South African beef bulls during three to 20 days of aging and on the muscle protease enzyme system during the first 20 hours post-mortem

\begin{tabular}{|c|c|c|c|c|c|}
\hline cast_763 & ${ }^{*} \mathrm{CC}(\mathrm{n}=113)$ & $\mathrm{CT}(\mathrm{n}=48)$ & ${ }^{\# T T}(\mathrm{n}=5)$ & $\begin{array}{l}P \text {-value } \\
\text { (simplified) }\end{array}$ & $\begin{array}{l}\text { Genotype } \\
\text { effect }\end{array}$ \\
\hline WBSF (d3) & $5.99^{a} \pm 0.11$ & $6.40^{a} \pm 0.17$ & - & 0.5672 & - \\
\hline WBSF (d9) & $4.69 a \pm 0.09$ & $4.97 \mathrm{a} \pm 0.15$ & - & 0.9146 & - \\
\hline WBSF (d14) & $4.09^{a} \pm 0.08$ & $4.27^{a} \pm 0.13$ & - & 0.7815 & - \\
\hline WBSF (d20) & $3.81^{\mathrm{a}} \pm 0.08$ & $3.93^{a} \pm 0.12$ & - & 0.9412 & - \\
\hline MFL (d3) & $34.77 \mathrm{y} \pm 0.52$ & $36.56^{z} \pm 0.85$ & - & 0.0902 & $-4.9 \%$ \\
\hline MFL (d9) & $25.64^{b} \pm 0.35$ & $27.14^{\mathrm{a}} \pm 0.57$ & - & 0.0289 & $-5.5 \%$ \\
\hline MFL (d14) & $23.38^{b} \pm 0.33$ & $24.45^{\mathrm{a}} \pm 0.54$ & - & 0.0005 & $-4.4 \%$ \\
\hline MFL (d20) & $21.28^{\mathrm{b}} \pm 0.27$ & $22.30^{a} \pm 0.43$ & - & 0.0081 & $-4.6 \%$ \\
\hline calpastatin (1h) & $1.96^{y} \pm 0.03$ & $2.07^{z} \pm 0.04$ & - & 0.0828 & $-5.5 \%$ \\
\hline calpastatin (20h) & $1.63^{\mathrm{a}} \pm 0.03$ & $1.76^{\mathrm{a}} \pm 0.05$ & - & 0.1042 & - \\
\hline calpain-1 (1h) & $1.40^{z} \pm 0.02$ & $1.42^{z} \pm 0.04$ & - & 0.0848 & $\mathrm{n} / \mathrm{a}$ \\
\hline calpain-1 (20h) & $1.04 \pm 0.03$ & $1.09 \pm 0.04$ & - & 0.3695 & - \\
\hline calpain-2 (1h) & $0.98 \pm 0.01$ & $1.00 \pm 0.02$ & - & 0.4187 & - \\
\hline calpain-2 (20h) & $1.01 \pm 0.01$ & $1.03 \pm 0.02$ & - & 0.5901 & - \\
\hline calpastatin/calpain-1 (1h) & $1.44 \pm 0.02$ & $1.50 \pm 0.03$ & - & 0.9886 & - \\
\hline calpastatin/calpain-1 (20h) & $1.69 \pm 0.04$ & $1.77 \pm 0.06$ & - & 0.4553 & - \\
\hline calpastatin/calpains(1h) & $0.83 \pm 0.01$ & $0.87 \pm 0.02$ & - & 0.5752 & - \\
\hline calpastatin/calpains (20h) & $0.80 \mathrm{y} \pm 0.01$ & $0.85^{z} \pm 0.02$ & - & 0.0876 & $-5.6 \%$ \\
\hline
\end{tabular}

${ }^{*} \mathrm{CC}$ - the genotype that favored tenderness; Least squares means (LSM) \pm standard errors (SE) that were significantly different within rows or aging periods $(\mathrm{P} \leq 0.05)$ were indicated with different ascending letter superscripts and those that tended to be significantly different $(\mathrm{P} \leq 0.10)$, with different descending letter superscripts $(\mathrm{z}, \mathrm{y}, \mathrm{x})$.

\# Tough homozygotes were not available for comparison; MFL - myofibril fragment length; WBSF - Warner-Bratzler shear force. 
The small differences in myofibril length can be ascribed to small changes in protease enzyme inhibition that tended to occur, but were not consistently present (Table 3). The absolute calpastatin inhibition at $1 \mathrm{~h}$ post-mortem associated with the genotype and was $5.5 \%$ lower, while relative calpastatin per combined calpain-1 and calpain-2 proteolysis at $20 \mathrm{~h}$ was $5.6 \%$ lower in the ${ }^{*} \mathrm{CC}$ genotype compared to CT. Although a tendency towards a decrease in calpain- 1 at $1 \mathrm{~h}$ was observed, the difference was biologically negligible (1.4\% shorter MFL) and can be considered unaffected by genotype.

3.2.3 capn2_780

The capn2_780 SNP (rs135646764) was located $55.07 \mathrm{~kb}$ from the start of the gene. The SNP was in LD (D'>0.95) with other SNP that affected tenderness in the gene-based association study, capn2_760 (-46.93 kb), capn2_763 (-35.72 kb), capn2_766 (-26.53 kb) and capn2_772 $(-21.40 \mathrm{~kb})$. Selection for the tender allele of the capn2_780 SNP would include indirect selection for these SNP, all of which were linked to the corresponding tender alleles. These SNP were found to have no association with WBSF or MFL, but did affect changes in enzyme function, which was a general increase in calpastatin and calpains, where calpain proteolysis increased to a greater extent than calpastatin inhibition. This resulted in a decrease in the relative calpastatin inhibition per units of calpain proteolysis, which would favor tenderization (results not shown). The tough GG genotype was relatively rare $(n=15)$, where 10 of these bulls were Brahman, while also not being sufficient for determining LSM. The G allele was rare in Angus, with only three heterozygotes and no GG bulls. Genotype differences were therefore compared for $\mathrm{AA}^{*}(\mathrm{n}=112)$ compared to AG ( $n=39)$, except in Angus where the association could not be tested.

There were no associations between genotypes and WBSF at any of the aging periods (Table 4), while the capn2_780 genotype tended to affect MFL throughout the aging period (Figure 2a). The tenderizing effect of the SNP on MFL on d 14 was only apparent when breed(s) were added to the simplified model as covariate(s). The tender, or AA* genotype resulted in a $>6 \%$ reduction in MFL compared to AG on $\mathrm{d} 3$ and $\mathrm{d} 9$, which was sustained as a small, $5.4 \%$ decrease on $\mathrm{d} 20$. Although these tenderizing effects were biologically small, they were additive to a 39\% decrease in MFL already induced by aging in both genotypes (Figure 2a).

The covariate effect of breed(s) was only present on d 14 post-mortem (Figure 2b), where Bonsmara MFL remained unchanged, while tenderizing effects of the genotype was moderate in Brahman (8.1\%) and large in Charolais (15.6\%). The $\mathrm{AA}^{*}$ genotype in Nguni bulls resulted in a $6.9 \%$ increase in myofibril lengths, or $1.54 \mu \mathrm{m}$, which is not a tenderizing response.

The fact that the consistent decrease in MFL over the aging period was not accompanied by a concomitant decrease in shear force values at any of the aging periods was most likely due to a lack of changes in the proteolytic enzymes in the different genotypes (Table 4). 
Table 4. The effects of genotype of the capn2_780 SNP on the tenderness phenotype, Warner-Bratzler shear force (WBSF) of representative purebred South African beef bulls during three to 20 days of aging and on the muscle protease enzyme system during the first 20 hours post-mortem

\begin{tabular}{llllll}
\hline capn2_780 & ${ }^{*} \mathrm{AA}(\mathrm{n}=112)$ & $\mathrm{AG}(\mathrm{n}=39)$ & $\mathrm{GG}(\mathrm{n}=15)$ & $\begin{array}{l}P \text {-value } \\
\text { (simplified) }\end{array}$ & $\begin{array}{l}\text { Genotype } \\
\text { effect }\end{array}$ \\
\hline WBSF (d3) & $6.05 \pm 0.11$ & $6.54 \pm 0.20$ & - & 0.3279 & - \\
WBSF (d9) & $4.77 \pm 0.09$ & $4.83 \pm 0.17$ & - & 0.1467 & - \\
WBSF (d14) & $4.10 \pm 0.08$ & $4.30 \pm 0.15$ & - & 0.2274 & - \\
WBSF (d20) & $3.84 \pm 0.08$ & $3.93 \pm 0.14$ & - & 0.3831 & - \\
\hline calpastatin (1h) & $2.06 \pm 0.03$ & $1.87 \pm 0.05$ & - & 0.9969 & - \\
calpastatin (20h) & $1.75 \pm 0.03$ & $1.48 \pm 0.06$ & - & 0.7869 & - \\
calpain-1 (1h) & $1.45 \pm 0.02$ & $1.35 \pm 0.04$ & - & 0.3737 & - \\
calpain-1 (20h) & $1.10 \pm 0.03$ & $0.99 \pm 0.05$ & - & 0.3225 & - \\
calpain-2 (1h) & $1.00 \pm 0.01$ & $0.95 \pm 0.02$ & - & 0.9139 & - \\
calpain-2 (20h) & $1.03 \pm 0.01$ & $0.96 \pm 0.02$ & - & 0.6730 & - \\
calpastatin/calpain-1 (1h) & $1.47 \pm 0.02$ & $1.42 \pm 0.04$ & - & 0.7586 & - \\
calpastatin/calpain-1 (20h) & $1.74 \pm 0.04$ & $1.62 \pm 0.07$ & - & 0.9579 & - \\
calpastatin/calpains(1h) & $0.85 \pm 0.01$ & $0.82 \pm 0.02$ & - & 0.7954 & - \\
calpastatin/calpains (20h) & $0.83 \pm 0.01$ & $0.77 \pm 0.02$ & - & 0.7862 & - \\
\hline
\end{tabular}

${ }^{*} \mathrm{AA}$ - the genotype that favored tenderness; Least squares means (LSM) \pm standard errors (SE) were not significantly different $(\mathrm{P}>0.10)$. \# Tough homozygotes were not available for comparison; WBSF - Warner-Bratzler shear force. 
(a)

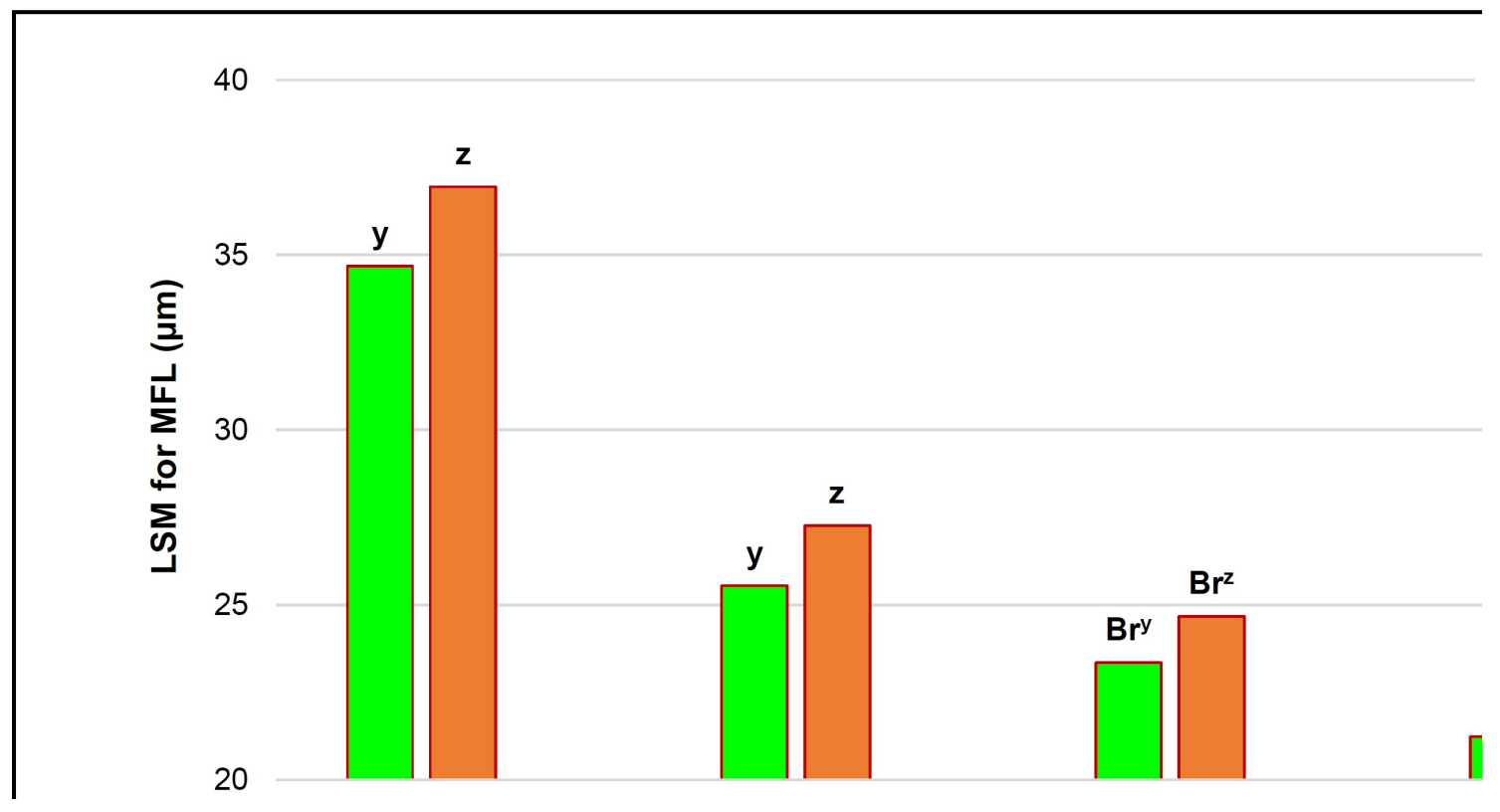

(b)

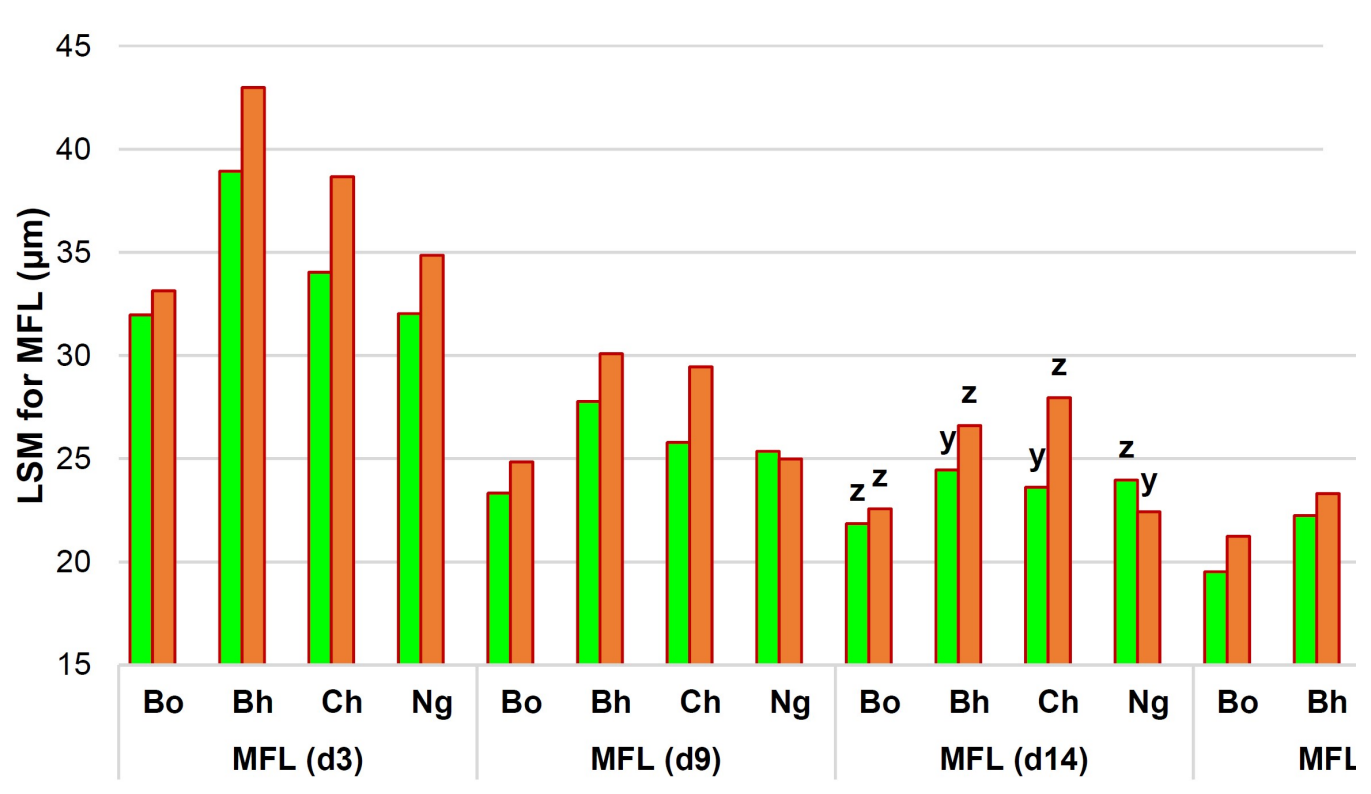

Figure 2. Additive effects of the capn2_780 genotype and ageing on myofibril fragment length (MFL). AA* - the genotype that favored tenderness. Within each ageing period, different descending letter superscripts $(\mathrm{z}, \mathrm{y}, \mathrm{x})$ tended to be significantly different $(\mathrm{P} \leq 0.10)$ : (a) Genotype and ageing effects data pooled for all breeds; $\mathrm{Br}$ - different only when breeds were added to the simplified model; (b) Genotype and ageing effects on MFL for individual South African beef breeds. Bo - Bonsmara; Bh - Brahman; Ch - Charolais; Ng - Nguni.

\subsection{4 capn1_184}

The capn1_184 SNP (rs17871986) was located $4.51 \mathrm{~kb}$ from the start of the gene and exhibited a high level of LD (D'>0.95) with three other SNP associated with tenderness within close proximity of the SNP. The selection for the tender, G* allele of capn1_184 favors selection for the "tender alleles" for these SNP that are closely linked to it (unpublished results). The capn1_183 (-0.76 kb) capn1_316 SNP (+1.10 kb) and capn1_185 $(+2.96 \mathrm{~kb})$ SNP were all associated with increased tenderization, with similar or smaller 
means differences than those discussed below. There was a shortage of tough homozygous bulls (AA) in Bos taurus and Sanga types and a lack of tender homozygotes $\left(\mathrm{GG}^{*}\right)$ in Brahman. However, addition of breed(s) as covariate(s) did not improve the simplified mixed model in any of the phenotypes tested. A greater pool of animals will be required to fully elucidate the breed differences, if any.

The capn1_184 SNP exhibited a strong, stable association with WBSF over the entire aging period (Figure 3a) and during intermediate aging ( $\mathrm{d} 9-\mathrm{d} 14$ ) for MFL (Table 5), resulting in large phenotypic responses $(\geq 19 \%)$. The differences between means observed for the different genotypes sustained levels greater than $1 \mathrm{~kg}$ shear force throughout the different aging periods, where a $20.3 \%$ decrease in WBSF of d 3 was maintained throughout, up to $22.8 \%$ on $\mathrm{d} 20$. These genotype associations were additive to decreases in WBSF of between $34.2-37.1 \%$ in all three genotypes over the aging period (Figure 3a). Similar results were observed for MFL at d 9 and $\mathrm{d} 14$ of aging, where myofibril lengths in $\mathrm{GG}^{*}$ bulls were $7.31 \mu \mathrm{m}$ and $8.04 \mu \mathrm{m}$ shorter than AA bulls respectively.

Large, consistent decreases in WBSF and large, but less consistent shorter MFL were likely the result of the associations of the capn1_184 SNP with the inhibition of calpastatin, relative to protease activities (Figure $3 \mathrm{~b}$ ). The calpastatin per calpain-1 at $1 \mathrm{~h}$ and 20 h decreased by $\geq 19 \%$, while calpastatin per combined calpain- 1 and calpain- 2 activities at $1 \mathrm{~h}$ was $17 \%$ lower. The LSM for heterozygous bulls was intermediate for calpastatin per unit of calpain-1 proteolysis, but not different from the tender genotype for inhibition relative to combined proteolysis of calpain-1 and calpain-2. This would allow for increased degradation of muscle proteins, greatly favoring the tenderization of beef.

3.2.5 capn1_187

The capn1_187 SNP (rs135658374) was located $17.59 \mathrm{~kb}$ from the start of the gene and was in strong LD (D'>0.95) with the capn1_4751 SNP (+6.57 kb) discussed below. The distribution of alleles for Brahman was skewed toward the tough allele, while other breeds generally experienced a shortage of CC genotypes. The discussion will therefore focus on the differences between the tender homozygous bulls ( $\mathrm{TT}^{*}$ ) and heterozygotes (CT) for breed-dependence, although there was little or no advantage to adding breeds to the simplified model as covariates.

The SNP was associated with WBSF over the entire aging period. The least squares means differences between homozygous bulls were very close to $1 \mathrm{~kg}$ on $\mathrm{d} 3$ and $\mathrm{d} 9$ post-mortem $(0.43-0.49 \mathrm{~kg}$ for heterozygous bulls) and the large gain in tenderness of early aging was decreased somewhat by $\mathrm{d} 20$, where shear force was improved by $0.77 \mathrm{~kg}$ in $\mathrm{TT}^{*}$ and $0.34 \mathrm{~kg}$ in CT. These genotype effects on shear force occurred additive to the $37 \%$ reduction in WBSF that occurred in all genotypes by d 20 post-mortem (Figure 4a).

The association of the capn1_187 genotype with MFL decayed over the time of aging, with the most prominent effect on $\mathrm{d} 3$, where an $11.78 \mu \mathrm{m}$ decrease in length was observed in $\mathrm{TT}^{*}$ bulls (26.6\% shorter). As the aging period progressed, the improvement in MFL gradually decreased and was $5.42 \mu \mathrm{m}(18.2 \%)$ on $\mathrm{d} 9$ and non-significant by $\mathrm{d} 14$.

There was a tendency toward a breed-dependent association of the capn1_187 SNP and absolute calpastatin at $20 \mathrm{~h}$ (Table 6). A large increase in absolute inhibition (toughening) was observed in Angus, Brahman and Charolais (+13-15\%), with no effect in Bonsmara and a moderate tenderizing response (11\% lower calpastatin) in Nguni. Although this apparent toughening effect was concerning, the means differences for relative calpastatin activity per calpain(s) was generally unaffected, while relative calpastatin inhibition per calpain-1 at $1 \mathrm{~h}$ was tenderizing (15.5\% lower). 
Table 5. The effects of genotype of the capn1_184 SNP on the tenderness phenotype, myofibril fragment length (MFL) of representative purebred South African beef bulls during three to 20 days of aging and on the muscle protease enzyme system during the first 20 hours post-mortem

\begin{tabular}{llllll}
\hline capn1_184 & *GG (n=77) & AG (n=66) & AA (n=23) & $\begin{array}{c}\text { P-value } \\
\text { (simplified) }\end{array}$ & $\begin{array}{c}\text { Genotype } \\
\text { effect }\end{array}$ \\
\hline MFL (d3) & $33.47^{\mathrm{a}} \pm 0.65$ & $35.48^{\mathrm{a}} \pm 0.72$ & $41.57^{\mathrm{a}} \pm 1.74$ & 0.1810 & - \\
MFL (d9) & $24.67 \mathrm{c} \pm 0.42$ & $26.20^{\mathrm{b}} \pm 0.47$ & $31.98^{\mathrm{a}} \pm 1.12$ & 0.0242 & $-22.9 \%$ \\
MFL (d14) & $22.50 \mathrm{y} \pm 0.38$ & $24.05 \mathrm{y} \pm 0.42$ & $30.54^{\mathrm{z}} \pm 1.02$ & 0.0771 & $-26.3 \%$ \\
MFL (d20) & $20.92 \pm 0.31$ & $21.54 \pm 0.35$ & $25.70 \pm 0.84$ & 0.1557 & - \\
\hline calpastatin (1h) & $1.99 \pm 0.04$ & $1.99 \pm 0.04$ & $2.23 \pm 0.09$ & 0.4096 & - \\
calpastatin (20h) & $1.69 \pm 0.04$ & $1.64 \pm 0.05$ & $1.81 \pm 0.11$ & 0.6957 & - \\
calpain-1 (1h) & $1.47 \pm 0.03$ & $1.41 \pm 0.03$ & $1.32 \pm 0.08$ & 0.2095 & - \\
calpain-1 (20h) & $1.13 \pm 0.03$ & $1.05 \pm 0.04$ & $0.97 \pm 0.09$ & 0.7597 & - \\
calpain-2 (1h) & $1.00 \pm 0.01$ & $1.00 \pm 0.01$ & $0.98 \pm 0.03$ & 0.7125 & - \\
calpain-2 (20h) & $1.04 \pm 0.01$ & $1.02 \pm 0.01$ & $0.98 \pm 0.04$ & 0.5729 & - \\
\hline
\end{tabular}

${ }^{*} \mathrm{GG}$ - the genotype that favored tenderness; Least squares means (LSM) \pm standard errors (SE) that were significantly different within rows or aging periods $(\mathrm{P} \leq 0.05)$ were indicated with different ascending letter superscripts and those that tended to be significantly different $(\mathrm{P} \leq 0.10)$, with different descending letter superscripts $(\mathrm{z}, \mathrm{y}, \mathrm{x})$. MFL - myofibril fragment length. 
(a)

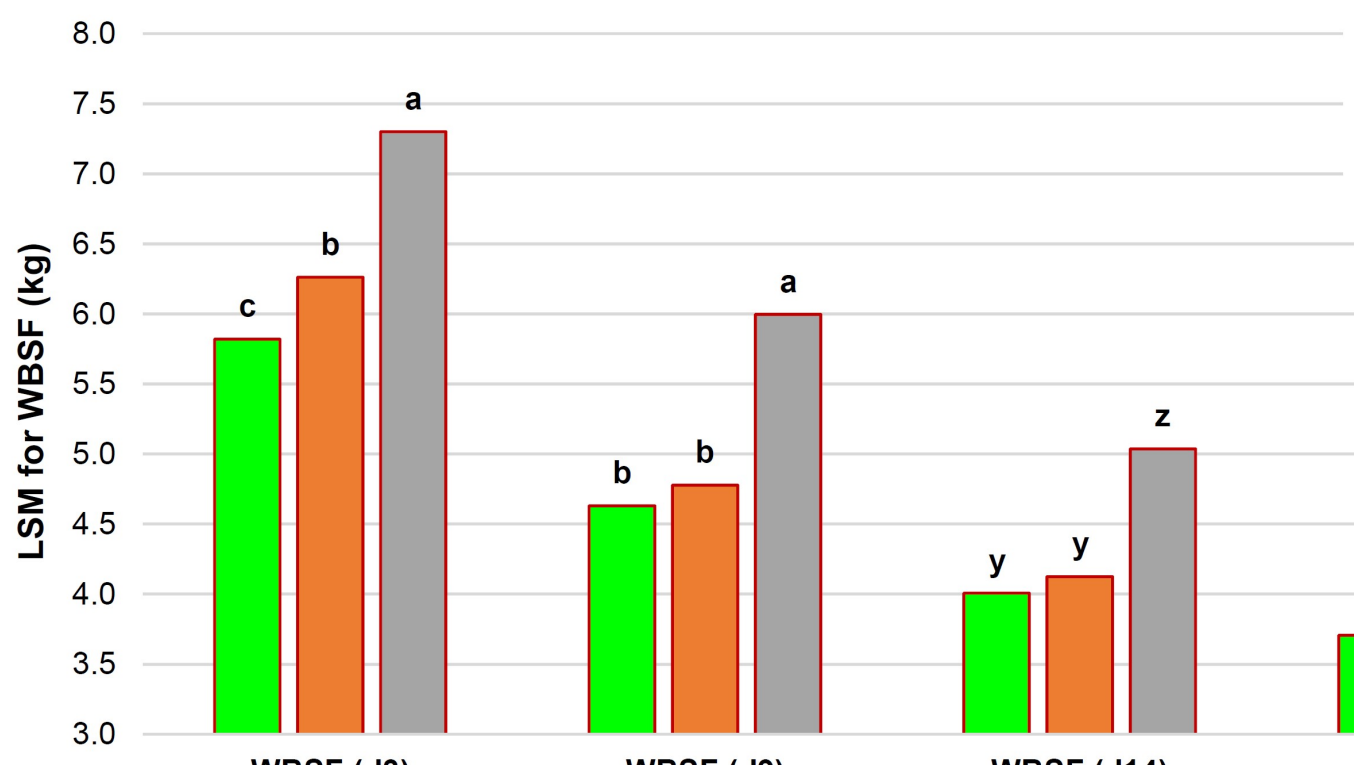

(b)

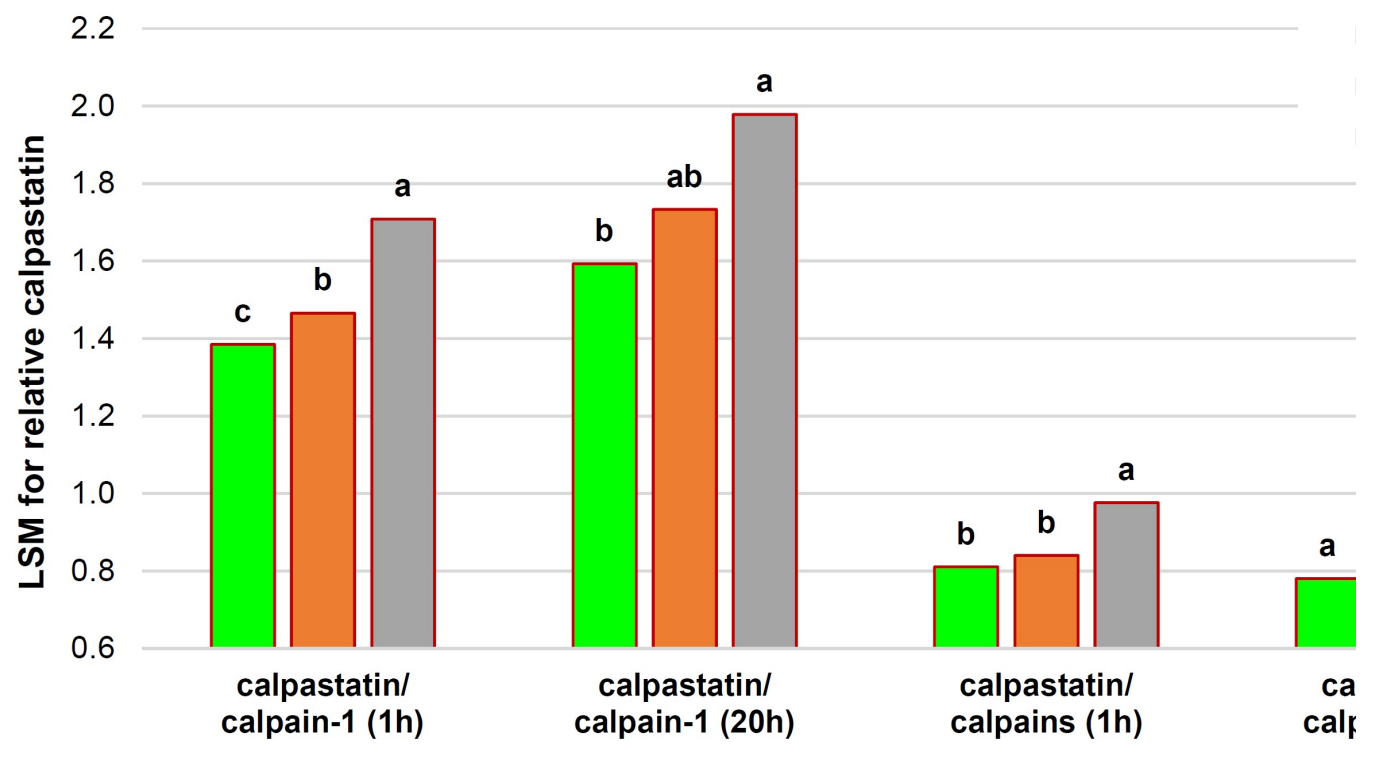

Figure 3. Additive effects of the capn1_184 genotype and aging on tenderness in representative purebred South African beef bulls. $G^{*}$ - the genotype that favored tenderness. Within each aging period, different ascending letter superscripts $(\mathrm{a}, \mathrm{b}, \mathrm{c})$ were significantly different $P \leq 0.05)$ and those that tended to be different $P \leq 0.10$ ) were indicated with different descending letter superscripts $(\mathrm{z}, \mathrm{y}, \mathrm{x})$ : (a) Warner-Bratzler shear force (WBSF); (b) Relative calpastatin inhibition of protease(s). 
Table 6. The effects of genotype of the capn1_187 SNP on the tenderness phenotype, myofibril fragment length (MFL) of representative purebred South African beef bulls during three to 20 days of aging and on the muscle protease enzyme system during the first 20 hours post-mortem

\begin{tabular}{|c|c|c|c|c|c|}
\hline capn1_187 & ${ }^{*} \mathrm{TT}(\mathrm{n}=76)$ & $\mathrm{CT}(\mathrm{n}=57)$ & $C C(n=33)$ & $\begin{array}{l}P \text {-value } \\
\text { (simplified) }\end{array}$ & $\begin{array}{l}\text { Genotype } \\
\text { effect }\end{array}$ \\
\hline MFL (d3) & $32.54^{c} \pm 0.64$ & $35.33^{b} \pm 0.76$ & $44.32^{\mathrm{a}} \pm 2.10$ & 0.0090 & $-26.6 \%$ \\
\hline MFL (d9) & $24.30^{c} \pm 0.43$ & $26.23^{b} \pm 0.51$ & $29.71^{\mathrm{a}} \pm 1.40$ & 0.0047 & $-18.2 \%$ \\
\hline MFL (d14) & $22.25 \pm 0.40$ & $24.38 \pm 0.47$ & $26.65 \pm 1.30$ & 0.1270 & - \\
\hline MFL (d20) & $20.61 \pm 0.32$ & $21.80 \pm 0.38$ & $24.02 \pm 1.06$ & 0.1885 & - \\
\hline calpastatin (1h) & $2.00 \pm 0.04$ & $2.04 \pm 0.04$ & $1.96 \pm 0.12$ & 0.2181 & \\
\hline calpastatin (20h) & $1.73^{z} \pm 0.04$ & $1.69 \mathrm{z} \pm 0.05$ & $1.61^{z} \pm 0.14$ & 0.0640 & \#variable \\
\hline calpastatin/calpain-1 (1h) & $1.38^{z} \pm 0.02$ & $1.44^{z} \pm 0.03$ & $1.63 \mathrm{y} \pm 0.08$ & 0.0909 & $-15.5 \%$ \\
\hline calpastatin/calpain-1 (20h) & $1.63 \pm 0.05$ & $1.69 \pm 0.06$ & $1.84 \pm 0.16$ & 0.1571 & \\
\hline calpastatin/calpains(1h) & $0.81 \pm 0.01$ & $0.83 \pm 0.01$ & $0.90 \pm 0.04$ & 0.1989 & \\
\hline calpastatin/calpains (20h) & $0.79 \pm 0.01$ & $0.80 \pm 0.02$ & $0.85 \pm 0.04$ & 0.5493 & \\
\hline
\end{tabular}

*TT - the genotype that favored tenderness; Least squares means (LSM) \pm standard errors (SE) that were significantly different within rows or aging periods $(\mathrm{P} \leq 0.05)$ were indicated with different ascending letter superscripts and those that tended to be significantly different $(\mathrm{P} \leq 0.10)$, with different descending letter superscripts $(\mathrm{z}, \mathrm{y}, \mathrm{x})$.

\# Responses of the ${ }^{*}$ TT genotype was variable between breeds and not always tenderizing; MFL - myofibril fragment length. 
(a)

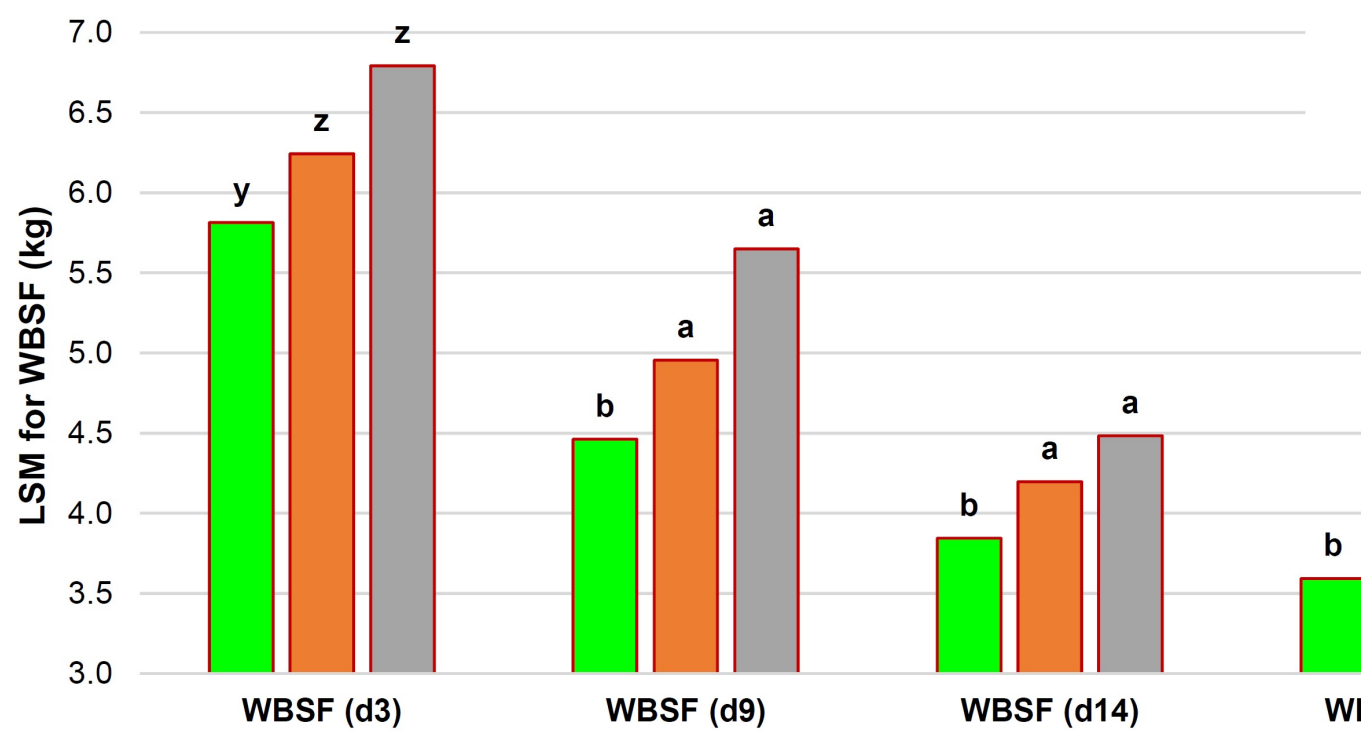

1.6

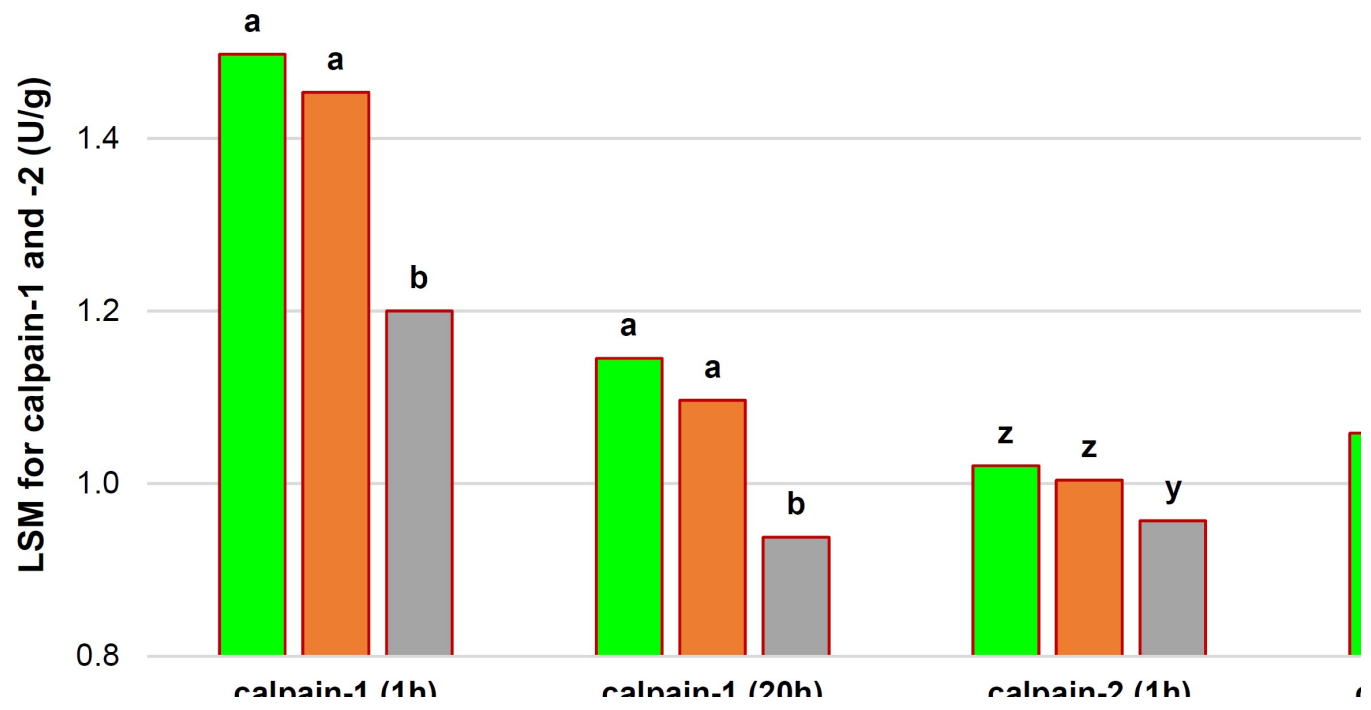

Figure 4. Additive effects of the capn1_187 genotype and ageing on tenderness in representative purebred South African beef bulls. TT* ${ }^{*}$ the genotype that favored tenderness. Within each ageing period, different ascending letter superscripts $(a, b, c)$ were significantly different $\mathrm{P} \leq 0.05)$ and those that tended to be significantly different $\mathrm{P} \leq 0.10)$ were indicated with different descending letter superscripts ( $\mathrm{z}, \mathrm{y}, \mathrm{x})$ : (a) Warner-Bratzler shear force (WBSF); (b) Calpain protease activities. 
The large consistent responses in tenderization (especially WBSF) were therefore not in reaction to decreased calpastatin inhibition of protease activities, but rather large and consistent responses of the proteases themselves to genotypes (Figure $4 \mathrm{~b}$ ). Increased protease activity in genotypes that contained the $\mathrm{T}^{*}$ allele were large for muscle calpain-1 activities $(17-25 \%)$, with moderate tenderizing effects in calpain-2 $(\leq 10 \%)$. These increased rates of proteolysis would favor myofibrillar fragmentation, decreasing the length of the fibrils and favoring a decrease in shear force values.

3.2.6 capn1_4751

The capn1-4751 SNP (rs17872050) was located $24.17 \mathrm{~kb}$ from the start of the capn1 gene. It exhibited strong LD (D'>0.95) with the capn1_187 SNP discussed above (-1.86 kb) and some downstream SNP, with the tender allele for capn1_4751, corresponding to the tender alles of these SNP (results not shown). The capn1_189 SNP (+6.04 kb), capn1_190 $(+10.34 \mathrm{~kb})$ and capn1_191 (+13.79 kb) decreased WBSF in late aging by between $9.0 \%$ on d 14 up to $16.2 \%$ on d 20 and selection for the capn_4751 SNP would result in favorable responses in these tenderness phenotypes.

The SNP associated with WBSF only between $\mathrm{d} 14$ and $\mathrm{d} 20$, resulting in a moderate tenderization of $0.47-0.50 \mathrm{~kg}$ shear force (Table 7 ), additive to the existing aging tenderizing effects. The association between the capn1-4751 SNP and MFL was however sustained from d 3 to $\mathrm{d} 14$ post-mortem, although the effects on myofibril lengths were moderate. MFL was decreased by $10.4 \%$ on $\mathrm{d} 3,9.3 \%$ on $\mathrm{d} 9$ and $8.1 \%$ on $\mathrm{d} 14$ in CC $\mathrm{C}^{*}$ bulls compared to TT. These moderate gains are still important, as they occurred additive to $32-33 \%$ decrease in MFL than occurred between $\mathrm{d} 9-\mathrm{d} 20$ of aging and the genotype effect deteriorated, but did not disappear over time in late aging as myofibril lengths decreased. There was no advantage to adding breeds to the simplified mixed model as covariates.

The only other effect of the capn1_4751 genotype on tenderizing phenotypes was an increase in calpain-1 protease activity at $1 \mathrm{~h}$ post-mortem, although this effect was biologically small. The protease activity of $\mathrm{CC}^{*}$ bulls was $7.7 \%$ greater than $\mathrm{CT}$, with an intermediate increase in tender homozygotes compared to TT (Table 7).

\section{Discussion}

Of the total of 134 SNP tested in the gene-based association analyzes, 62 SNP showed some association with tenderness phenotypes WBSF or MFL, on at least one of the aging periods $(P \leq 0.10)$, while 38 SNP associated significantly $(P \leq 0.05)$ with tenderness (results not shown). Only 12 of these SNP, or less than $20 \%$ associated with tenderness over extended periods of aging, before quality control or biological importance of differences were considered. For these SNP, it was more likely to identify associations from data collected at a single aging period or from animals that show variation in aging, where $92 \%$ of associations would be identified if any one aging period was used to determine both WBSF and MFL. However, more than $80 \%$ of the SNP that could affect tenderness would likely fail to associate with tenderness from a single measurement, because they only associated with tenderness phenotypes for a short period of aging. The least likely aging period to identify an association in these data was d 9, where only $40 \%$ of all the possible SNP (24/62) showed association with WBSF or MFL, while at the other aging periods (d 3, d 14 and d 20), approximately $50-55 \%$ of all possible associations were identified. 
Table 7. The effects of genotype of the capn1_4751 SNP on the tenderness phenotypes, Warner-Bratzler shear force (WBSF) and myofibril fragment length (MFL) of representative purebred South African beef bulls during three to 20 days of aging and on the muscle protease enzyme system during the first 20 hours post-mortem

\begin{tabular}{llllll}
\hline capn1_4751 & ${ }^{*}$ CC $(\mathrm{n}=53)$ & $\mathrm{CT}(\mathrm{n}=63)$ & $\mathrm{TT}(\mathrm{n}=50)$ & $\begin{array}{l}P \text {-value } \\
\text { (simplified) }\end{array}$ & $\begin{array}{l}\text { Genotype } \\
\text { effect }\end{array}$ \\
\hline WBSF (d3) & $5.89^{\mathrm{a}} \pm 0.16$ & $6.17^{\mathrm{a}} \pm 0.15$ & $6.26^{\mathrm{a}} \pm 0.22$ & 0.3758 & - \\
WBSF (d9) & $4.47^{\mathrm{a}} \pm 0.14$ & $4.94^{\mathrm{a}} \pm 0.13$ & $4.85^{\mathrm{a}} \pm 0.19$ & 0.3035 & - \\
WBSF (d14) & $3.84^{\mathrm{b} \pm 0.12}$ & $4.14^{\mathrm{ab} \pm 0.11}$ & $4.31^{\mathrm{a}} \pm 0.17$ & 0.0357 & $-10.8 \%$ \\
WBSF (d20) & $3.58^{\mathrm{b}} \pm 0.11$ & $3.88^{\mathrm{ab} \pm 0.11}$ & $4.07^{\mathrm{a}} \pm 0.16$ & 0.0226 & $-12.0 \%$ \\
\hline MFL (d3) & $32.43^{\mathrm{y}} \pm 0.79$ & $35.72^{\mathrm{z}} \pm 0.73$ & $36.17^{\mathrm{a}} \pm 1.09$ & 0.0790 & $-10.4 \%$ \\
MFL (d9) & $24.20^{\mathrm{b}} \pm 0.52$ & $26.14^{\mathrm{a}} \pm 0.48$ & $26.69^{\mathrm{a}} \pm 0.72$ & 0.0474 & $-9.3 \%$ \\
MFL (d14) & $22.11^{\mathrm{y}} \pm 0.49$ & $24.36^{\mathrm{z}} \pm 0.45$ & $24.07^{\mathrm{a}} \pm 0.67$ & 0.0762 & $-8.1 \%$ \\
MFL (d20) & $20.32^{\mathrm{a}} \pm 0.40$ & $21.90^{\mathrm{a}} \pm 0.37$ & $21.94^{\mathrm{a}} \pm 0.55$ & 0.1056 & - \\
\hline calpastatin (1h) & $2.02^{\mathrm{a}} \pm 0.04$ & $2.03^{\mathrm{a}} \pm 0.04$ & $2.08^{\mathrm{a}} \pm 0.06$ & 0.1216 & - \\
calpastatin (20h) & $1.73^{\mathrm{a}} \pm 0.05$ & $1.73^{\mathrm{a}} \pm 0.05$ & $1.74^{\mathrm{a}} \pm 0.07$ & 0.1424 & - \\
calpain-1 (1h) & $1.54^{\mathrm{a}} \pm 0.03$ & $1.43^{\mathrm{b}} \pm 0.03$ & $1.48^{\mathrm{a}} \pm 0.05$ & 0.0340 & $+4.1 \%$ \\
calpain-1 (20h) & $1.14 \pm 0.04$ & $1.13 \pm 0.04$ & $1.08 \pm 0.05$ & 0.1847 & - \\
calpain-2 (1h) & $1.03 \pm 0.01$ & $1.00 \pm 0.01$ & $1.03 \pm 0.02$ & 0.2252 & - \\
calpain-2 (20h) & $1.05 \pm 0.02$ & $1.04 \pm 0.01$ & $1.03 \pm 0.02$ & 0.3517 & - \\
calpastatin/calpain-1 (1h) & $1.35 \pm 0.03$ & $1.45 \pm 0.03$ & $1.46 \pm 0.04$ & 0.3813 & - \\
calpastatin/calpain-1 (20h) & $1.64 \pm 0.06$ & $1.69 \pm 0.05$ & $1.77 \pm 0.08$ & 0.7056 & - \\
calpastatin/calpains(1h) & $0.79 \pm 0.01$ & $0.84 \pm 0.01$ & $0.84 \pm 0.02$ & 0.8265 & - \\
calpastatin/calpains (20h) & $0.79 \pm 0.02$ & $0.80 \pm 0.02$ & $0.83 \pm 0.02$ & 0.3613 & - \\
\hline
\end{tabular}

${ }^{*} \mathrm{CC}-$ the genotype that favored tenderness; Least squares means (LSM) \pm standard errors (SE) that were significantly different within rows or aging periods $(\mathrm{P} \leq 0.05)$ were indicated with different ascending letter superscripts and those that tended to be significantly different $(\mathrm{P} \leq 0.10)$, with different descending letter superscripts $(\mathrm{z}, \mathrm{y}, \mathrm{x})$.

MFL - myofibril fragment length; WBSF - Warner-Bratzler shear force. 
Although the effects of genotypes in the calpain-calpastatin system are well-established, few studies have formally investigated the changes induced by aging over time, especially not using high-definition (777K) genotyping in South African beef cattle. Here, the SNP in the cast and capn2 gene that could sustain tenderizing effects for extended aging periods were rare and did not have large effects on a variety of phenotypes of physical tenderness or protease activity. Previous studies similarly identified a limited number of 777K SNP in the capn1 and cast genes associated with tenderness, but these associations were limited to earlier aging periods $(\leq \mathrm{d} 7)$ and did not extend into the $\mathrm{d} 14$, intermediate aging period [67]. In our data, there were however a few SNP in the capn1 gene with larger, sustained phenotypic responses in the tender genotypes (genotypes containing tender alleles) and could be linked physiologically to responses in the muscle calpain-calpastatin system.

Linkage disequilibrium (LD) is a requirement for effective genomic selection $[68,69]$, but can also cause inadvertent negative effects from SNP that are not targeted through selection [70], but linked in inheritance or pleiotropy [71]. Additionally, genotyping needs to be conducted at a sufficiently high density to identify LD between SNP markers $[16,72,73]$ or the correlation in inheritance between alleles from different loci. The mean LD (D') between SNP in the cast and capn2 genes was high, 0.84 and 0.92 respectively, while greater levels of diversity (moderate D') were present in the capn1 (0.69) and the capn3 (0.63) genes. All the SNP in LD with the candidate SNP for extended aging were also linked to tender alleles that would result in responses that favor tenderness, with no apparent unintended negative effects on tenderization [70]. In addition to tenderness, other phenotypes like color, energy supply and water-holding capacity were recorded, but no clear adverse effects were identified through LD (results not shown).

It must be considered that the SNP in this study were specifically chosen to sustain an effect on tenderness (WBSF or MFL) over time. If the three genotypes of a SNP responded to aging in the same way, the association with the phenotype should remain relatively unaffected over the aging period. One could assume that this should be true for the SNP identified in this study and this was generally true, with little difference in the absolute size of the tenderizing response $(\mathrm{kg}$ or $\mu \mathrm{m})$ between $\mathrm{d} 3-\mathrm{d} 20$, within each of the genotypes (bulls homozygous for the tender alleles, heterozygotes and bulls homozygous for the tough alleles).

If there is an interaction between the individual genotypes $\times$ tenderization over aging period, one genotype tenderizes more (or less) than the other genotypes over time. Longer aging periods are generally employed to allow beef that tenderizes at a slower rate, to reach a greater tenderness before going to market. Over time, the differences between tough steaks in early aging and those that tenderize rapidly by early aging can decrease and even become negligible [9]. One could expect that it would become more difficult to identify genomic effects after longer periods of aging (e.g. d 20), because the differences between the means of the toughest vs. most tender steaks, decreased over time. An example of such an effect was shown in the capn1_187 SNP, where the change in MFL of the $\mathrm{TT}^{*}$ and CT genotypes (containing the tender allele) as $11.93 \mu \mathrm{m}$ and $13.53 \mu \mathrm{m}$ respectively (a $37-38 \%$ decrease in myofibril length to $\mathrm{d} 20$ ). However, the change in the CC genotype was $20.3 \mu \mathrm{m}$ or $45.8 \%$ between d 3 to d 20 and because the bulls with the "tough genotype" exhibited a greater response to aging, the beneficial effect of the $\mathrm{T}^{*}$ allele also gradually disappeared over time.

For this same SNP however (capn1_187), the effect on WBSF was generally very stable and there was little difference between the responses of bulls with different genotypes to aging for 20 days. Tender homozygous bulls (TT*) experienced a $2.22 \mathrm{~kg}$ reduction in WBSF (38.2\%), heterozygous bulls $2.32 \mathrm{~kg}$ (37.1\%) tough homozygous (CC) bulls $2.43 \mathrm{~kg}$ $(35.7 \%)$. The differences between means of the genotypes therefore remained very stable over the different aging periods, with little difference between $\mathrm{d} 3$ and $\mathrm{d} 20$ in the percentage difference of $\mathrm{TT}^{*}$ compared to $\mathrm{CC}$. This large tenderizing response, from very early aging would be the ideal in a candidate SNP, because it would eliminate the finan- 
cial and logistical costs associated with extended aging, therefore increasing profitability $[11,12]$.

Conversely, the association of the cast_736 SNP on MFL changed dramatically over time from an effect of attenuated tenderization of $\mathrm{GG}^{*}$ bulls on $\mathrm{d} 9$, to a tenderizing effect of the same genotype on $\mathrm{d} 20$. This dramatic change in the association between $\mathrm{d} 9$ and d 20 was the result of an enhanced response to aging in the GG* genotype, where the change in myofibril lengths of these bulls was $7.24 \mu \mathrm{m}$ between $\mathrm{d} 9-\mathrm{d} 20$, but only $4.1 \mu \mathrm{m}$ in GT and $4.53 \mu \mathrm{m}$ in TT.

The effects of the cast_736 SNP on WBSF that increased during aging to a $10 \%$ decrease in shear force by d 14 in $\mathrm{GG}^{*}$ bulls was promising. It was previously identified as a candidate SNP for selection for tenderness on approximately d 3 and d 14 of aging [74]. The cast_736 SNP fell within the range of a quantitative trait loci (QTL) for shear force identified previously, but was not one of the candidate SNP tested by the 50K array used [75] and is also included in the GeneSeek HD Genomic Profiler (150K). Previous studies failed to associate the genotype of this SNP with tenderizing effects $[67,76]$. The moderate tenderizing response that was retained well into aging could represent a meaningful gain in tenderness above either GT or TT bulls on $\mathrm{d} 20$, if the proportion of GG* bulls can be increased through selection for this SNP. It would also have to be targeted specifically for selection, as it did not show LD with any other candidate SNP in this experiment. To our knowledge, this is the first association of this SNP with tenderness phenotypes and confirms a role for the SNP in the QTL that could be independent of the other SNP in the QTL. However, the effects on MFL and calpastatin that accompany this improvement in WBSF precludes the use of the SNP, as an unintended negative response in calpastatin inhibition (an increase) could result in decreased proteolysis and increased toughening. The counterintuitive, toughening effect of the SNP on calpastatin in the "tender" genotype could explain the inconsistent effects in MFL.

Although the present results showed small but persistent effects of the cast_763 SNP on WBSF, previous studies have failed to identify an association between the SNP and tenderization [74]. Although the SNP falls within the location of a shear force QTL in the gene, the cast_763 SNP was not included in the these analyzes as a potential candidate SNP $[75,77,78]$ or did not associate with tenderness $[67,76]$. Even though these effects were small, they proved statistically significant in both models used to analyze these data. It follows that a small potential exists for an improvement in the marker through selection that would be linked to improvements in early and intermediate aging through LD with neighboring SNP, including measures of WBSF, which were not significant for the SNP itself, as part of the QTL in this region of the gene [75]. This SNP is however already distributed toward the favorable allele, with a large proportion of $\mathrm{CC}^{*}$ bulls $(n=113)$. This is characteristic of many SNP in the cast gene [79-81], where the average tender allele frequency from all 77 SNP genotyped in the cast gene averaged $71.3 \%$, being the minor allele in only nine $(12 \%)$ of these SNP. This could be the result of selection practices, as confirmed by the relatively high LD of the gene $\left(D^{\prime}=0.84\right)$.

The capn2_780 SNP generally only tended to have a small effect on MFL, but was persistent through most of the aging periods tested. It was linked to SNP that could favor responses in the muscle calpain system in this study that could indirectly enhance tenderization through proteolysis in selection. Although SNP in the capn2 gene were tested as possible candidates for selection for tenderness [82], this SNP has not yet been causally linked to tenderness $[67,75,76]$.

The capn1_184 SNP is located within QTL for tenderness phenotypes (shear force and panel score), where it has been linked to WBSF [67], while other studies have found no association of the SNP with tenderness [74,75,77]. It was an excellent candidate for selection to improve tenderness over the entire aging period for representative South African beef breeds, while positive gains would also be made in the SNP through LD. Not only did the association of this SNP with WBSF persist over the entire aging period, but there were large gains during the intermediate aging period ( $\mathrm{d} 9$ and $\mathrm{d} 14$ ) and the $21-26 \%$ improvement in tenderness $(\leq \mathrm{d} 14)$ was much greater than the $7 \%$ improvement 
in WBSF or $9 \%$ in MFL between d $14-\mathrm{d} 20$. This implies that beef could go to market sooner and this $1.1 \mathrm{~kg}$ difference in shear values between genotypes is large enough to make a considerable (perceptible) difference to the consumer. These results are in stark contrast with a previous study that failed to show an association of this SNP with direct or indirect measures of tenderness on d 3 or d 14 of aging [74].

The capn1_187 and capn1_4751 SNP were candidates for extended effects on tenderness throughout aging in this study. They were slightly less effective than capn1_184 in determining WBSF, at least as effective for MFL and had more pronounced effects on calpain protease activities. The capn1_4751 SNP was also linked to downstream SNP that caused at least similar responses in tenderization. The capn1-4751 SNP was the only of the SNP studied here that has been identified as a causal SNP in QTL for shear force [75,78] and has been consistently included in research papers since its discovery in 2005 [83] and is included in most of the high throughput arrays and commercial chips.

Although capn1_187 was not identified as a candidate for selection for tenderness of beef $[67,76]$, capn1_4751 associated with several measures of tenderness in many studies. The capn1-187 SNP was located within the range of QTL for shear force, but not included as a genotype in these research articles $[75,77,78]$. The large response in tenderization during early ageing of these SNP was the ideal pattern of association, increasing tenderness rapidly within the first days of ageing, even though a diminishing effect of genotype on tenderness was noted in later ageing [47,48]. The association of the capn1-187 SNP with tenderness phenotypes could arise from its strong LD with the causal SNP, capn1-4751, through association in inheritance, rather than an effect on the calpain-1 large subunit protein itself. The capn1_4751 SNP has been shown to exhibit very low tender allelic frequencies in some Brahman [84] and both capn1_4751 and capn1_187 showed only $10 \%$ tender alleles in the Brahman breed, where the effect of the SNP remained tenderizing.

The present results agree with that of previous studies [74], namely that there were no significant interactions between breeds and genotype effects, although the phenotypes themselves were subject to breed effects. This means that although there are differences between breeds for allelic frequencies, the associations of these SNP with phenotypes remain intact within the different breeds and the SNP could be used across different populations [74], as long as they remain polymorphic. This absence of breed effects could be the result of the conservation of these critical genes in evolution, because they perform a fundamental function as modulator proteins maintaining normal cellular function $[85,86]$. It is however difficult to draw any firm conclusions from the relatively small number of animals genotyped here and detailed phenotypic data from a large number of animals subjected to high density genotyping or sequencing [85,86], will be required to confirm these observations. Brahman favorable allelic frequency was consistently below the average for all four genes, but particularly in capn1 where it was only $15.8 \%$ (vs the average $50.8 \%$ tender alleles in capn 1 ).

\section{Conclusions}

One possible way of decreasing the effective aging period is through genomic selection for SNP that (ideally) accelerate aging over extended periods of time. However, the duration of aging can alter genomic associations over time. Some of the SNP in the muscle calpain system sustained genomic associations with tenderness throughout extended aging periods, while some individual genotypes also responded differently to aging, altering these associations over time. We found that aging was accelerated in some tough genotypes in the cast and capn1 genes, compared to genotypes that contained the tender alleles, progressively eroding genotype differences as aging was extended.

Author Contributions: Lorinda Frylinck originally conceptualized the project, acquired funding and made considerable contributions in project administration, investigation, review and editing. Annie Basson was involved in conceptualizing the research and responsible for formal analysis, 
writing the original draft preparation, visualization, review and editing, under the supervision of Lorinda Frylinck with co-supervision by Phillip Strydom, Esté van Marle-Köster and Edward Webb. Phillip Strydom contributed in conceptualizing, investigation, review and editing. Edward Webb and Esté van Marle-Köster were involved in conceptualizing, review and editing. All authors have read and agreed to the published version of the manuscript.

Funding: This research was funded by Red Meat Research and Development South Africa (RMRDSA) (Genomic markers in beef tenderness) and the Technology and Human Resources for Industry Programme of the Department of Trade and Industry (DTI THRIP), South Africa (TP2011071900006).

Institutional Review Board Statement: All treatments and procedures were approved by the Ethics Committee of the Animal Production Institute of the Agricultural Research Council (ARC AEC I 2010 001) and the Animal Care Committee of the University of Pretoria (EC171114 161).

Acknowledgements: We hereby acknowledge the Agricultural Research Council - Animal Production (ARC-AP) for facilities and animal care. The abattoir and laboratory personnel of the ARC-AP (Meat Science and Technology) for sample collection and analysis.

Conflicts of Interest: The authors declare no conflict of interest.

\section{References}

1. Culler, R.D.; Parrish, F.C.; Smith, G.C.; Cross, H.R. Relationship of myofibril fragmentation index to certain chemical, physical and sensory characteristics of bovine longissimus muscle. Journal of Food Science 1978, 43, 1177-1180, doi:10.1111/j.1365-2621.1978.tb15263.x.

2. Koohmaraie, $\mathrm{M}$. The role of $\mathrm{Ca}^{2+}$-dependent proteases (calpains) in post mortem proteolysis and meat tenderness. Biochimie 1992, 74, 239-245, doi:10.1016/0300-9084(92)90122-U.

3. Koohmaraie, M.; Seidemann, S.C.; Schollmeyer, J.E.; Dutson, T.R.; Crouse, J.D. Effect of post-mortem storage on $\mathrm{Ca}^{++}$-dependent proteases, their inhibitor and myofibril fragmentation. Meat Science 1987, 19, 187-196, doi:10.1016/0309-1740(87)90056-8.

4. Morton, J.D.; Bickerstaffe, R.; Kent, M.P.; Dransfield, E.; Keeley, G.M. Calpain-calpastatin and toughness in M. longissimus from electrically stimulated lamb and beef carcasses. Meat Science 1999, 52, 71-79, doi:10.1016/S0309-1740(98)00150-8.

5. Geesink, G.H.; Kuchay, S.; Chishti, A.H.; Koohmaraie, M. $\mu$-Calpain is essential for postmortem proteolysis of muscle proteins. Journal of Animal Science 2006, 84, 2834-2840, doi:10.2527/jas.2006-122.

6. Koohmaraie, M.; Geesink, G.H. Contribution of postmortem muscle biochemistry to the delivery of consistent meat quality with particular focus on the calpain system. Meat Science 2006, 74, 34-43, doi:10.1016/j.meatsci.2006.04.025.

7. Colle, M.J.; Doumit, M.E. Effect of extended aging on calpain-1 and -2 activity in beef longissimus lumborum and semimembranosus muscles. Meat Science 2017, 131, 142-145, doi:10.1016/j.meatsci.2017.05.014.

8. Lian, T.; Wang, L.; Liu, Y. A new insight into the role of calpains in post-mortem meat tenderization in domestic animals: A review. Asian-Australasian Journal of Animal Science 2013, 26, 443-454, doi:10.5713/ajas.2012.12365.

9. Watanabe, A.; Daly, C.C.; Devine, C.E. The effects of the ultimate $\mathrm{pH}$ of meat on tenderness changes during ageing. Meat Science 1996, 42, 67-78, doi:10.1016/0309-1740(95)00012-7.

10. O'Connor, S.F.; Tatum, J.D.; Wulf, D.M.; Green, R.D.; Smith, G.C. Genetic effects on beef tenderness in Bos indicus composite and Bos taurus cattle. Journal of Animal Science 1997, 75, 1822-1830, doi:10.2527/1997.7571822x.

11. Warner, R.D.; McDonnell, C.K.; Bekhit, A.E.D.; Claus, J.; Vaskoska, R.; Sikes, A.; Dunshea, F.R.; Ha, M. Systematic review of emerging and innovative technologies for meat tenderisation. Meat Science 2017, 132, 72-89, doi:10.1016/j.meatsci.2017.04.241.

12. Dransfield, E. Optimisation of tenderisation, ageing and tenderness. Meat Science 1994, 36, 105-121, doi:10.1016/0309-1740(94)90037-X.

13. Taylor, J.F.; McKay, S.D.; Rolf, M.M.; Ramey, H.R.; Decker, J.E.; Schnabel, R.D. Genomic selection in beef cattle. In Bovine Genomics; Womack, J., Ed.; John Wiley \& Sons, Incorporated: Hoboken, USA, 2012; pp. 211-233 ISBN 9781118301715.

14. Allais, S.; Journaux, L.; Levéziel, H.; Payet-Duprat, N.; Raynaud, P.; Hocquette, J.F.; Lepetit, J.; Rousset, S.; Denoyelle, C.; Bernard-Capel, C.; Renand, G. Effects of polymorphisms in the calpastatin and $\mu$-calpain genes on meat tenderness in 3 French beef breeds. Journal of Animal Science 2011, 89, 1-11, doi:10.2527/jas.2010-3063.

15. Madilindi, M.A.; Banga, C.B.; Bhebhe, E.; Sanarana, Y.P.; Nxumalo, K.S.; Taela, M.G.; Magagula, B.S.; Mapholi, N.O. Genetic diversity and relationships among three Southern African Nguni cattle populations. Tropical Animal Health and Production 2020, 52, 753-762, doi:10.1007/s11250-019-02066-y.

16. Makina, S.O.; Taylor, J.F.; Van Marle-Köster, E.; Muchadeyi, F.C.; Makgahlela, M.L.; MacNeil, M.D.; Maiwashe, A. Extent of linkage disequilibrium and effective population size in four South African Sanga cattle breeds. Frontiers in Genetics 2015, 6, 337 (1-12), doi:10.3389/fgene.2015.00337.

17. Wang, M.D.; Dzama, K.; Hefer, C.A.; Muchadeyi, F.C. Genomic population structure and prevalence of copy number variations in South African Nguni cattle. BMC Genomics 2015, 16, 894, doi:10.1186/s12864-015-2122-z. 
18. Makina, S.O.; Muchadeyi, F.C.; Van Marle-Köster, E.; MacNeill, M.D.; Maiwashe, A. Genetic diversity and population structure among six cattle breeds in South Africa using a whole genome SNP panel. Frontiers in Genetics 2014, 5, 333 (1-7), doi:10.3389/fgene.2014.00333.

19. Makina, S.O.; Muchadeyi, F.C.; Van Marle-Köster, E.; Taylor, J.F.; Makgahlela, M.L.; Maiwashe, A. Genome-wide scan for selection signatures in six cattle breeds in South Africa. Genetics Selection Evolution 2015, 47, 92 (1-14), doi:10.1186/s12711-015-0173-x.

20. Qwabe, S.O.; Van Marle-Köster, E.; Maiwashe, A.; Muchadeyi, F.C. Evaluation of the BovineSNP50 genotyping array in four South African cattle populations. South African Journal of Animal Science 2013, 43, 64-67, doi:10.4314/sajas.v43i.7.

21. Bosman, L.; Van.der Westhuizen, R.R.; Visser, C.; Van Marle-Köster, E. Influence of population structure on the compilation of the Bonsmara genomic reference population. Advances in Animal Biosciences 2017, 8, s45-s47, doi:10.1017/S2040470017001686.

22. Van.der Westhuizen, R.R.; Van Marle-Köster, E.; Theron, H.E.; Van.der Westhuizen, J. Reference population for South African Bonsmara cattle. In Proceedings of the Proceedings of the 10th World Congress of Genetics Applied to Livestock Production; American Society of Animal Science (ASAS), 2014; p. 498.

23. Zwane, A.A.; Maiwashe, A.; Makgahlela, M.L.; Choudhury, A.; Taylor, J.F.; Van Marle-Köster, E. Genome-wide identification of breed-informative single-nucleotide polymorphisms in three South African indigenous cattle breeds. South African Journal of Animal Science 2016, 46, 302-312, doi:10.4314/sajas.v46i3.10.

24. Mapholi, N.O.; Maiwashe, A.; Matika, O.; Riggio, V.; Bishop, S.C.; MacNeil, M.D.; Banga, C.; Taylor, J.F.; Dzama, K. Genome-wide association study of tick resistance in South African Nguni cattle. Ticks and Tick-borne Diseases 2016, 7, 487-497, doi:10.1016/j.ttbdis.2016.02.005.

25. Zwane, A.A.; Schnabel, R.D.; Hoff, J.; Choudhury, A.; Makgahlela, M.L.; Maiwashe, A.; Van Marle-Köster, E.; Taylor, J.F. Genome-wide SNP discovery in indigenous cattle breeds of South Africa. Frontiers in Genetics 2019, 10, 273.1-16, doi:10.3389/fgene.2019.00273.

26. Frylinck, L.; Van Wyk, G.L.; Smith, T.P.L.; Strydom, P.E.; Van Marle-Köster, E.; Webb, E.C.; Koohmaraie, M.; Smith, M.F. Evaluation of biochemical parameters and genetic markers for association with meat tenderness in South African feedlot cattle. Meat Science 2009, 83, 657-665, doi:10.1016/j.meatsci.2009.07.016.

27. Raza, S.H.A.; Khan, S.; Amjadi, M.; Abdelnour, S.A.; Ohran, H.; Alanazi, K.M.; El-Hack, M.E.A.; Taha, A.E.; Khan, R.; Gong, C.; Schreurs, N.M.; Zhao, C.; Wei, D.; Zan, L. Genome-wide association studies reveal novel loci associated with carcass and body measures in beef cattle. Archives of Biochemistry and Biophysics 2020, 694, 108543, doi:https://doi.org/10.1016/j.abb.2020.108543.

28. Williams, J.L.; Dunner, S.; Valentini, A.; Mazza, R.; Amarger, V.; Checa, M.L.; Crisà, A.; Razzaq, N.; Delourme, D.; Grandjean, F.; Marchitelli, C.; García, D.; Pérez Gomez, R.; Negrini, R.; Ajmone Marsan, P.; Levéziel, H. Discovery, characterization and validation of single nucleotide polymorphisms within 206 bovine genes that may be considered as candidate genes for beef production and quality. Animal Genetics 2009, 40, 486-491, doi:10.1111/j.1365-2052.2009.01874.x.

29. Mullen, A.M.; Stapleton, P.C.; Corcoran, D.; Hamill, R.M.; White, A. Understanding meat quality through the application of genomic and proteomic approaches. Meat Science 2006, 74, 3-16, doi:10.1016/j.meatsci.2006.04.015.

30. Warner, R.D.; Greenwood, P.L.; Pethick, D.W.; Ferguson, D.M. Genetic and environmental effects on meat quality. Meat Science 2010, 86, 171-183, doi:10.1016/j.meatsci.2010.04.042.

31. Sierra, V.; Fernández-Suárez, V.; Castro, P.; Osoro, K.; Vega-Naredo, I.; García-Macía, M.; Rodríguez-Colunga, P.; Coto-Montes, A.; Oliván, M. Identification of biomarkers of meat tenderisation and its use for early classification of Asturian beef into fast and late tenderising meat. Journal of the Science of Food and Agriculture 2012, 92, 2727-2740, doi:10.1002/jsfa.5701.

32. Burrow, H.M.; Moore, S.S.; Johnston, D.J.; Barendse, W.; Bindon, B.M. Quantitative and molecular genetic influences on properties of beef: A review. Australian Journal of Experimental Agriculture 2001, 41, 893-919, doi:10.1071/EA00015.

33. Minick, J.A.; Dikeman, M.E.; Pollak, E.J.; Wilson, D.E. Heritability and correlation estimates of Warner-Bratzler shear force and carcass traits from Angus-, Charolais-, Hereford-, and Simmental-sired cattle. Canadian Journal of Animal Science 2004, 84, 599-609, doi:10.4141/A03-060.

34. Smith, T.; Domingue, J.D.; Paschal, J.C.; Franke, D.E.; Bidner, T.D.; Whipple, G. Genetic parameters for growth and carcass traits of Brahman steers. Journal of Animal Science 2007, 85, 1377-1384, doi:10.2527/jas.2006-653.

35. Iso-Touru, T.; Pesonen, M.; Fischer, D.; Huuskonen, A.; Sironen, A. The effect of CAPN1 and CAST gene variations on meat quality traits in Finnish Aberdeen Angus and Nordic Red Cattle populations. Agricultural and Food Science 2018, 27, 227-231, doi:10.23986/afsci.75125.

36. Guillocheau, G.; Hou, A.E.; Meerssemann, C.; Esquerré, D.; Rebours, E.; Letaief, R.; Simao, M.; Hypolite, N.; Bourneuf, E.; Bruneau, N.; Vaiman, A.; Jagt, C.J.V.; Chamberlain, A.J.; Rocha, D. Survey of allele specific expression in bovine muscle. Scientific Reports 2019, 9, hal-02619712 .1-12, doi:10.1038/s41598-019-40781-6.

37. Bennett, G.L.; Tait Jr., R.G.; Shackelford, S.D.; Wheeler, T.L.; King, D.A.; Casas, E.; Smith, T.P.L. Enhanced estimates of carcass and meat quality effects for polymorphisms in myostatin and $\mu$-calpain genes. Journal of Animal Science 2019, 97, 569-577, doi:10.1093/jas/sky451.

38. Morris, C.A.; Cullen, N.G.; Hickey, S.M.; Dobbie, P.M.; Veenvliet, B.A.; Manley, T.R.; Pitchford, W.S.; Kruk, Z.A.; Bottema, C.D.K.; Wilson, T. Genotypic effects of calpain 1 and calpastatin on the tenderness of cooked M. longissimus dorsi steaks from Jersey X Limousin, Angus and Hereford-cross cattle. Animal Genetics 2006, 37, 411-414, doi:10.1111/j.1365-2052.2006.01483.x.

39. Iguácel, L.P.; Calvo, J.H.; Casasús, I.; Serrano, M.; Ripoll, G.; Sarto, P.; Villalba, D.; Blanco, M. Association of two single nucleotide polymorphisms in the calpastatin gene with tenderness under varying lengths of meat ageing in two native Spanish cattle breeds. Livestock Science 2019, 230, 103820, doi:10.1016/j.livsci.2019.103820. 
40. Wang, Y.; Zhang, F.; Mukiibi, R.; Chen, L.; Vinsky, M.; Plastow, G.; Basarab, J.; Stothard, P.; Li, C. Genetic architecture of quantitative traits in beef cattle revealed by genome wide association studies of imputed whole genome sequence variants: II: carcass merit traits. BMC Genomics 2020, 21, 38.1-22, doi:10.1186/s12864-019-6273.

41. Van Marle-Köster, E.; Visser, C.; Makgahlela, M.; Cloete, W.P. Genomic technologies for food security: A review of challenges and opportunities in Southern Africa. Food Research International 2015, 76, 971-979, doi:10.1016/j.foodres.2015.05.057.

42. Grigoletto, L.; Ferraz, J.B.S.; Oliveira, H.R.; Eler, J.P.; Bussiman, F.O.; Abreu Silva, B.C.; Baldi, F.; Brito, L.F. Genetic architecture of carcass and meat quality traits in Montana Tropical® composite beef cattle. Frontiers in Genetics 2020, 11, 123.1-13, doi:10.3389/fgene.2020.00123.

43. Marín-Garzón, N.A. Genome-wide association study identified genomic regions and putative candidate genes affecting meat color traits in Nellore cattle. Meat Science 2020, 171, 108288.1-12, doi:10.1016/j.meatsci.2020.108288.

44. Bolormaa, S.; Pryce, J.E.; Kemper, K.; Savin, K.; Hayes, B.J.; Barendse, W.; Zhang, Y.; Reich, C.M.; Mason, B.A.; Bunch, R.J.; Harrison, B.E.; Reverter, A.; Herd, R.M.; Tier, B.; Graser, H.-U.; Goddard, M.E. Accuracy of prediction of genomic breeding values for residual feed intake and carcass and meat quality traits in Bos taurus, Bos indicus, and composite beef cattle. Journal of Animal Science 2013, 91, 3088-3104, doi:10.2527/jas.2012-5827.

45. Pinto, L.F.B.; Ferraz, J.B.S.; Meirelles, F.V.; Eler, J.P.; Rezende, F.M.; Carvalho, M.E.; Almeida, H.B.; Silva, R.C.G. Association of SNPs on CAPN1 and CAST genes with tenderness in Nellore cattle. Genetics and Molecular Research 2010, 9, 1431-1442, doi:10.4238/vol9-3gmr881.

46. Castro, S.; Rís, M.; Ortiz, Y.; Manrique, C.; Jiménez, A.; Ariza, F. Association of single nucleotide polymorphisms in CAPN1, CAST and $M B$ genes with meat color of Brahman and crossbreed cattle. Meat Science 2016, 117, 44-49, doi:10.1016/j.meatsci.2016.02.021.

47. Mazzucco, J.P.; Melucci, L.M.; Villarreal, E.L.; Mezzadra, C.A.; Soria, L.; Corva, P.; Motter, M.M.; Schor, A.; Miquel, M.C. Effect of ageing and $\mu$-calpain markers on meat quality from Brangus steers finished on pasture. Meat Science 2010, 86, 878-882, doi:10.1016/j.meatsci.2010.07.015.

48. Gruber, S.L.; Tatum, J.D.; Engle, T.E.; Chapman, P.L.; Enns, R.M.; Belk, K.E.; Smith, G.C. Effects of genetic markers and implant strategy on longissimus and gluteus muscle tenderness of calf-fed steers and heifers. Journal of Animal Science 2011, 89, 1401-1411, doi:10.2527/jas.2010-2893.

49. Chang, L.Y.; Pitchford, W.S.; Bottema, C.D.K. Modeling tenderness for genetic and quantitative trait loci analyses. Journal of Animal Science 2014, 92, 39-47, doi:10.2527/jas.2013-6696.

50. Schenkel, F.S.; Miller, S.P.; Jiang, Z.; Mandell, I.B.; Ye, X.; Li, H.; Wilton, J.W. Association of a single nucleotide polymorphism in the calpastatin gene with carcass and meat quality traits of beef cattle. Journal of Animal Science 2006, 84, 291-299, doi:10.2527/2006.842291x.

51. Anonymous Government Notice No. R. 1621 of 13 July 1990. Agricultural Products Standards Act (119/1990): To provide for control over the sale and export of certain agricultural products and other related products; and for matters connected therewith. Government Gazette No. 12641; Department of Agriculture, Forestry and Fisheries (DAFF) 1990, 301, 1-29.

52. Anonymous Government Notice No. R. 55 of 30 January 2015. Agricultural Product Standards Act (119/1990): Regulations regarding the classification and marking of meat intended for sale in the Republic of South Africa. Government Gazette No. 38431; Department of Agriculture, Forestry and Fisheries (DAFF) 2015, 595, 3-29.

53. Wheeler, T.L.; Shackelford, S.D.; Koohmaraie, M. Standardizing collection and interpretation of Warner-Bratzler shear force and sensory tenderness data. In Proceedings of the Proceedings of the 50th Annual Reciprocal Meat Science Conference; United States Department of Agriculture (USDA), Nebraska, USA, 1997; pp. 68-77.

54. AMSA AMSA Research guidelines for cookery, sensory evaluation, and instrumental tenderness measurements of meat; Second Edition.; American Meat Science Association, 2016; pp. 1-106;

55. Heinze, P.H.; Brueggemann, D. Ageing of beef: Influence of two ageing methods on sensory properties and myofibrillar proteins. Sciences Des Aliments 1994, 14, 387-399.

56. Geesink, G.H.; Koohmaraie, M. Effect of calpastatin on degradation of myofibrillar proteins by $\mu$-calpain under post-mortem conditions. Journal of Animal Science 1999, 77, 2685-2692, doi:10.2527/1999.77102685x.

57. Dransfield, E. Calpains from thaw rigor muscle. Meat Science 1996, 43, 311-320, doi:10.1016/s0309-1740(96)00022-8.

58. NCBI National Center for Biotechnology Information. Genome Data Viewer: Bos taurus assembly UMD_3.1.1 2021.

59. Purcell, S.; Neale, B.; Todd-Brown, K.; Thomas, L.; Ferreira, M.A.R.; Bender, D.; Maller, J.; Sklar, P.; Bakker, P.I.W. de; Daly, M.J.; Sham, P.C. PLINK: A tool set for whole-genome association and population-based linkage analyses. The American Journal of Human Genetics 2007, 81, 559-575, doi:doi:10.1086/519795.

60. Yang, J.; Zaitlen, N.A.; Goddard, M.E.; Visscher, P.M.; Price, A.L. Advantages and pitfalls in the application of mixed-model association methods. Nature Genetics 2014, 46, 100-106, doi:10.1038/ng.2876.

61. Yang, J.; Lee, S.H.; Goddard, M.E.; Visscher, P.M. GCTA: A Tool for Genome-wide Complex Trait Analysis. The American Journal of Human Genetics 2011, 88, 76-82, doi:10.1016/j.ajhg.2010.11.011.

62. SAS SAS/STAT User's Guide, Version 9.22. Statistical Analysis System Institute Inc., SAS Campus Drive, Cary, North Carolina, 275132010.

63. Barrett, J.C.; Fry, B.; Maller, J.; Daly, M.J. Haploview: analysis and visualization of LD and haplotype maps. Bioinformatics 2005, 21, 263-265, doi:10.1093/bioinformatics/bth457. 
64. Gabriel, S.B.; Schaffner, S.F.; Nguyen, H.; Moore, J.M.; Roy, J.; Blumenstiel, B.; Higgins, J.; DeFelice, M.; Lochner, A.; Faggart, M.; Liu-Cordero, S.N.; Rotimi, C.; Adeyemo, A.; Cooper, R.; Ward, R.; Lander, E.S.; Daly, M.J.; Altshuler, D. The structure of haplotype blocks in the human genome. Science 2002, 296, 2225-2229, doi:10.1126/science.1069424.

65. Lewontin, R.C. The interaction of selection and linkage. I. General considerations; Heterotic models. Genetics 1964, 49, 49-67.

66. Lewontin, R.C. The detection of linkage disequilibrium in molecular sequence data. Genetics 1995, 140, 377-388, doi:10.1093/genetics/140.1.377.

67. Tizioto, P.C.; Decker, J.E.; Taylor, J.F.; Schnabel, R.D.; Mudadu, M.A.; Silva, F.L.; Mourão, G.B.; Coutinho, L.L.; Tholon, P.; Sonstegard, T.S.; Rosa, A.N.; Alencar, M.M.; Tullio, R.R.; Medeiros, S.R.; Nassu, R.T.; Feijó, G.L.D.; Silva, L.O.C.; Torres, R.A.; Siqueira, F.; Higa, R.H.; et al. Genome scan for meat quality traits in Nelore beef cattle. Physiological Genomics 2013, 45, 1012-1020, doi:10.1152/physiolgenomics.00066.2013.

68. Meuwissen, T.H.E.; Hayes, B.J.; Goddard, M.E. Prediction of total genetic value using genome-wide dense marker maps. Genetics 2001, 157, 1819-1829, doi:10.1093/genetics/157.4.1819.

69. Wientjes, Y.C.J.; Veerkamp, R.F.; Calus, M.P.L. The effect of linkage disequilibrium and family relationships on the reliability of genomic prediction. Genetics 2013, 193, 621-631, doi:10.1534/genetics.112.146290.

70. Wright, S. Genic and organismic selection. Evolution 1980, 34, 825-843, doi:10.2307/2407990.

71. Williams, J.L. The use of marker-assisted selection in animal breeding and biotechnology. Revue Scientifique et Technique-Office International des Epizooties 2005, 24, 379-391.

72. McKay, S.D.; Schnabel, R.D.; Murdoch, B.M.; Matukumalli, L.K.; Aerts, J.; Coppieters, W.; Crews, D.; Neto, E.D.; Gill, C.A.; Gao, C.; Mannen, H.; Stothard, P.; Wang, Z.; Tassell, C.P.V.; Williams, J.L.; Taylor, J.F.; Moore, S.S. Whole genome linkage disequilibrium maps in cattle. BMC Genetics 2007, 8, 74.1-74.12, doi:10.1186/1471-2156-8-74.

73. Pérez O’Brien, A.M.; Mészáros, G.; Utsunomiya, Y.T.; Sonstegard, T.S.; Garcia, J.F.; Van Tassell, C.P.; Carvalheiro, R.; Silva, M.V.B. da; Sölkner, J. Linkage disequilibrium levels in Bos indicus and Bos taurus cattle using medium and high density SNP chip data and different minor allele frequency distributions. Livestock Science 2014, 166, 121-132, doi:doi:10.1016/j.livsci.2014.05.007.

74. White, K.L. Novel traits for genetic selection in Gelbvieh influenced cattle, Kansas State University: Department of Animal Sciences \& Industry College of Agriculture Kansas State University Manhattan, Kansas, 2020.

75. McClure, M.C.; Ramey, H.R.; Rolf, M.M.; McKay, S.D.; Decker, J.E.; Chapple, R.H.; Kim, J.W.; Taxis, T.M.; Weaber, R.L.; Schnabel, R.D.; Taylor, J.F. Genome-wide association analysis for quantitative trait loci influencing Warner-Bratzler shear force in five taurine cattle breeds. Animal Genetics 2012, 43, 662-673, doi:10.1111/j.1365-2052.2012.02323.x.

76. Bolormaa, S.; Pryce, J.E.; Kemper, K.E.; Hayes, B.J.; Zhang, Y.; Tier, B.; Barendse, W.; Reverter, A.; Goddard, M.E. Detection of quantitative trait loci in Bos indicus and Bos taurus cattle using genome-wide association studies. Genetics Selection Evolution 2013, 45, 43:1-43:12, doi:10.1186/1297-9686-45-43.

77. Lee, S.-H.; Kim, S.-C.; Chai, H.-H.; Cho, S.-H.; Kim, H.-C.; Lim, D.; Choi, B.-H.; Dang, C.-G.; Sharma, A.; Gondro, C.; Yang, B.-S.; Hong, S.-K. Mutations in calpastatin and $\mu$-calpain are associated with meat tenderness, flavor and juiciness in Hanwoo (Korean cattle): Molecular modeling of the effects of substitutions in the calpastatin/ $\mu$-calpain complex. Meat Science 2014, 96, 1501-1508, doi:10.1016/j.meatsci.2013.11.026.

78. Barendse, W. Haplotype analysis improved evidence for candidate genes for intramuscular fat percentage from a genome wide association study of cattle. PLoS ONE 2011, 6, e29601.1-e29601.13, doi:10.1371/journal.pone.0029601.

79. Curi, R.A.; Chardulo, L.A.L.; Giusti, J.; Silveira, A.C.; Martins, C.L.; Oliveira, H.N. de Assessment of GH1, CAPN1 and CAST polymorphisms as markers of carcass and meat traits in Bos indicus and Bos taurus-Bos indicus cross beef cattle. Meat Science 2010, 86, 915-920, doi:10.1016/j.meatsci.2010.07.016.

80. Johnston, D.J.; Graser, H.-U. Estimated gene frequencies of GeneSTAR markers and their size of effects on meat tenderness, marbling, and feed efficiency in temperate and tropical beef cattle breeds across a range of production systems. Journal of Animal Science 2010, 88, 1917-1935, doi:10.2527/jas.2009-2305.

81. King, D.A.; Shackelford, S.D.; McDaneld, T.G.; Kuehn, L.A.; Kemp, C.M.; Smith, T.P.L.; Wheeler, T.L.; Koohmaraie, M. Associations of genetic markers in cattle receiving differing implant protocols. Journal of Animal Science 2012, 90, 2410-2423, doi:10.2527/jas.2011-4693.

82. Costello, S.; O’Doherty, E.; Troy, D.J.; Ernst, C.W.; Kim, K.S.; Stapleton, P.; Sweeney, T.; Mullen, A.M. Association of polymorphisms in the calpain I, calpain II and growth hormone genes with tenderness in bovine M. longissimus dorsi. Meat Science 2007, 75, 551-557, doi:10.1016/j.meatsci.2006.06.021.

83. White, S.N.; Casas, E.; Wheeler, T.L.; Shackelford, S.D.; Koohmaraie, M.; Riley, D.G.; Chase, C.C. Jr.; Johnson, D.D.; Keele, J.W.; Smith, T.P.L. A new single nucleotide polymorphism in CAPN1 extends the current tenderness marker test to include cattle of Bos indicus, Bos taurus, and crossbred descent. Journal of Animal Science 2005, 83, 2001-2008, doi:10.2527/2005.8392001x.

84. Smith, T.; Thomas, M.G.; Bidner, T.D.; Paschal, J.C.; Franke, D.E. Single nucleotide polymorphisms in Brahman steers and their association with carcass and tenderness traits. Genetics and Molecular Research 2009, 8, 39-46, doi:10.4238/vol8-1gmr537.

85. Ono, Y.; Sorimachi, H. Calpains - An elaborate proteolytic system. Biochimica et Biophysica Acta (BBA) - Proteins and Proteomics Special Issue 2012, 1824, 224-236, doi:10.1016/j.bbapap.2011.08.005.

86. Spinozzi, S.; Albini, S.; Best, H.; Richard, I. Calpains for dummies: What you need to know about the calpain family. Biochimica et Biophysica Acta (BBA) - Proteins and Proteomics 2021, 1869, 140616.1-12, doi:10.1016/j.bbapap.2021.140616Get rights and content. 